\title{
Fates and Travel Times of Denmark Strait Overflow Water in the Irminger Basin*
}

\author{
IngA M. KoszalKa AND Thomas W. N. HaIne \\ Earth and Planetary Sciences, Johns Hopkins University, Baltimore, Maryland \\ MARCELlo G. MAGALDI \\ Consiglio Nazionale delle Ricerche, Istituto di Scienze Marine, Lerici, Italy, and Earth and Planetary Sciences, \\ Johns Hopkins University, Baltimore, Maryland
}

(Manuscript received 18 January 2013, in final form 21 August 2013)

\begin{abstract}
The Denmark Strait Overflow (DSO) supplies about one-third of the North Atlantic Deep Water and is critical to global thermohaline circulation. Knowledge of the pathways of DSO through the Irminger Basin and its transformation there is still incomplete, however. The authors deploy over 10000 Lagrangian particles at the Denmark Strait in a high-resolution ocean model to study these issues. First, the particle trajectories show that the mean position and potential density of dense waters cascading over the Denmark Strait sill evolve consistently with hydrographic observations. These sill particles transit the Irminger Basin to the Spill Jet section $\left(65.25^{\circ} \mathrm{N}\right)$ in 5-7 days and to the Angmagssalik section $\left(63.5^{\circ} \mathrm{N}\right)$ in $2-3$ weeks. Second, the dense water pathways on the continental shelf are consistent with observations and particles released on the shelf in the strait constitute a significant fraction of the dense water particles recorded at the Angmagssalik section within 60 days $(\sim 25 \%)$. Some particles circulate on the shelf for several weeks before they spill off the shelf break and join the overflow from the sill. Third, there are two places where the water density following particle trajectories decreases rapidly due to intense mixing: to the southwest of the sill and southwest of the Kangerdlugssuaq Trough on the continental slope. After transformation in these places, the overflow particles exhibit a wide range of densities.
\end{abstract}

\section{Introduction}

The Denmark Strait Overflow (DSO) is one of the major export routes for the dense waters formed in the Arctic Ocean and the Nordic seas. The dense waters pass through the Irminger Basin (IB) toward the North Atlantic where they supply about one-third of the North Atlantic Deep Water, a major component of the global thermohaline circulation (Dickson and Brown 1994). The DSO transmits the climate signals from its source regions, modified en route by mixing and entrainment, and affects the properties throughout the water column in the North Atlantic (Dickson et al. 2008; Yashayaev and Dickson 2008).

\footnotetext{
* Supplemental information related to this paper is available at the Journals Online website: http://dx.doi.org/10.1175/JPO-D-13-023.s1.

Corresponding author address: Inga Koszalka, Earth and Planetary Sciences, Johns Hopkins University, 3400 N. Charles St., 301 Olin Hall, Baltimore, MD 21218.

E-mail: inga.koszalka@jhu.edu
}

The 620-m-deep Denmark Strait (DS) sill (DS sill) is the main gateway for dense waters exiting the Greenland Sea to the Irminger Basin and is a key location for observing the DSO at the start of its transit to the North Atlantic (Dickson et al. 2008). Measurements show that the dense overflow through the sill is fast (speeds frequently exceed $1 \mathrm{~m} \mathrm{~s}^{-1}$ ) and occurs as pulses of dense water (referred to as boluses) cascading to the deep water to the south of the sill at intervals of 2-5 days. On longer time scales, DSO appears as a steadier and hydraulically controlled flow with a mean transport of approximately $3 \mathrm{~Sv}\left(1 \mathrm{~Sv} \equiv 10^{6} \mathrm{~m}^{3} \mathrm{~s}^{-1}\right.$; Käse and Oschlies 2000; Macrander et al. 2007; Jochumsen et al. 2012). Temperature and salinity of DSO vary on a time scale of a few days, owing to mesoscale activity and intense mixing processes near the sill (Rudels et al. 1999; Tanhua et al. 2005). The seasonal signals in the DSO transport and properties are weak (Dickson and Brown 1994; Jochumsen et al. 2012). The overflow composition exhibits interannual-to-decadal variations; however, it is most likely linked to changes in the upstream source 
waters or pathways (Rudels et al. 2003). These changes in turn are possibly linked to atmospheric forcing and in particular to variations in the North Atlantic Oscillation (Yashayaev and Dickson 2008; Serra et al. 2010).

During the first $250 \mathrm{~km}$ of the DSO descent from the sill, hydrographic sections show that the mixing is intense (Voet and Quadfasel 2010). The volume transport nearly doubles through entrainment (Dickson et al. 2008), mainly of the warm and saline Irminger Current (Tanhua et al. 2008). Farther downstream, there are two major measurement sites used to monitor the dense overflow in the Irminger Basin. At the Spill Jet (SJ) section, $285 \mathrm{~km}$ southwest from DS sill, the DSO follows the continental slope transporting approximately $5 \mathrm{~Sv}$ (Brearley et al. 2012). ${ }^{1}$ The variability due to passage of the DSO boluses is pronounced at this site. The boluses are associated with cyclonic eddies that occupy intermediate and surface layers and are visible in satellite imagery (Bruce 1995; Spall and Price 1998). Ship surveys at the SJ section suggest that dense waters spill over the shelf break into the Irminger Basin (Rudels et al. 2002; Pickart et al. 2005; Falina et al. 2012). These spilling events are believed to feed the East Greenland Spill Jet, a strong flow of intermediate waters banked against the slope and overlying the DSO at the SJ section (Pickart et al. 2005). At $530 \mathrm{~km}$ downstream of the Denmark Strait, an array of current meters moored on the East Greenland slope off of Angmagssalik has been operated continuously since $1998 .^{2}$ At this section, the transport of DSO is estimated to have increased to over $7 \mathrm{~Sv}$ in a long-term average (Dickson et al. 2008). This increase is due to entrainment of Iceland-Scotland Overflow Water and Labrador Seawater (Tanhua et al. 2008). The variability due to the DSO boluses is less distinct at the Angmagssalik section; the dense plume is characterized by broad maxima in the frequency spectrum at 1-10 day periods (Voet and Quadfasel 2010).

There have been several modeling studies of the DSO. A series of papers considered the dynamics at the Denmark Strait sill (e.g., Spall and Price 1998; Käse and Oschlies 2000; Käse et al. 2003; Haine et al. 2009). Others, such as Köhl (2010) and Hall et al. (2011), adopted a large-scale perspective, focusing on the variability of the DSO source upstream of the Denmark Strait sill and its major pathways. The spatial discretizations of the models were too coarse to resolve the

\footnotetext{
${ }^{1}$ The dense current following the shelf break, comprising DSOW and entrained waters, is also referred to as the Deep Western Boundary Current (Brearley et al. 2012).

${ }^{2}$ Angmagssalik is the former name of the southeast Greenland town of Tasiilaq.
}

evolution of the DSO downstream of the sill. The highest resolution to date was achieved by the study of Magaldi et al. (2011, 2-km grid spacing in the horizontal and 97 vertical levels). Still, their configuration lacked adequate vertical resolution to resolve the dense boluses because the vertical grid spacing at the relevant depths $(2000 \mathrm{~m})$ was $100 \mathrm{~m}$, which is similar to the bolus height in the Irminger Basin [Käse et al. (2003), their Fig. 6].

Because of the sparseness of observations and the resolution limitations of numerical experiments, there are several open issues regarding the DSO in the Irminger Basin. First, the observations suggest there are alternate pathways of dense waters on the continental shelf in the Denmark Strait that are missed by the main measurement arrays. Dense water (potential density $\sigma_{\theta} \geq 27.8 \mathrm{~kg} \mathrm{~m}^{-3}$, where $\sigma_{\theta}=1000$ is potential density referenced to the surface; we will drop the unit thereafter and refer to potential density simply as "density") has repeatedly been observed on the shelf as far as $150 \mathrm{~km}$ northwest of the sill (Macrander et al. 2007; Brearley et al. 2012). It is also observed in the 650-m-deep Kangerdlugssuaq Trough (KT) intercepting Denmark Strait (Rudels et al. 2002). At the Dohrn Bank (DB; 50-100 km south of the sill) dense water has been observed to spill off the shelf and join the DSO (Rudels et al. 1999). The pathways of these dense waters on the shelf, their connection to spilling events at the Spill Jet section (Pickart et al. 2005), and their contribution to the overflow remain unclear.

Second, the DSO transformation rates that change the water temperature, salinity, and density downstream of the Denmark Strait are not well quantified. For this reason, it is difficult to identify DSO water (DSOW) at different measurement sites in the Irminger Basin or to estimate its volume transport. Dickson and Brown (1994) used a convenient criterion, $\sigma_{\theta} \geq 27.8$, to define the overflow component that contributes to North Atlantic Deep Water. On this basis, they drew an influential transport scheme for dense waters in the subpolar North Atlantic that describes the evolution of the DSO. The scheme shows a dense water plume crossing the Denmark Strait sill and proceeding south along the East Greenland slope through the Irminger Basin. Below, we call this scheme the "conventional" view of the overflow. The $\sigma_{\theta} \geq 27.8$ criterion has been widely used to track the DSOW in the Irminger Basin (Girton and Sanford 2003; Macrander et al. 2007; Köhl 2010; Magaldi et al. 2011; Brearley et al. 2012). The criterion is problematic, however, because of the water mass transformation that occurs in the Irminger Basin and the variability in the source-water properties of DSOW (Dickson et al. 2008; Brearley et al. 2012).

Third, the time scales of the DSO transit through the Irminger Basin are uncertain. The transit times are 
usually inferred by correlating hydrographic records from different stations. This method gives a time scale of 10 weeks for propagation from the Denmark Strait to the Angmagssalik section (Dickson et al. 2008). One can also estimate the advective time scale from the velocity records. The mean overflow speed in the Irminger Basin is $\sim 0.3 \mathrm{~m} \mathrm{~s}^{-1}$ (Girton and Sanford 2003; Dickson et al. 2008). This value implies a much shorter transit time of 3 weeks. It is unclear how to reconcile these estimates and how to relate them to trajectories of individual water particles.

This paper explores the pathways and evolution of the DSO in the Irminger Basin. We employ the Lagrangian (particle following) framework because it traces the water masses directly. Water property transformation is easily assessed from time series of the properties along particle trajectories (Döös 1995; Song and Rossby 1997; Dutkiewicz et al. 2001). Lagrangian instruments provide the high space-time resolution needed to resolve mesoscale and submesoscale processes that mix and exchange properties between water masses. To observe dense and deep flows, acoustically tracked subsurface floats have been used (Rossby et al. 1986). These floats have been successfully applied at the Iceland-Faroe Ridge and in the Norwegian Sea (Søiland et al. 2008; Rossby et al. 2009) but not yet in the DSO. In lieu of real observations, we use a high-resolution regional ocean model (Magaldi et al. 2011) and integrate over 10000 Lagrangian particles to study the transit of dense waters through the Irminger Basin. The particles are deployed on a section crossing the entire Denmark Strait in waters denser than $\sigma_{\theta}=27.8$ and advanced with threedimensional model velocity fields.

The paper is organized as follows. Section 2 presents the numerical model and the particle integration technique. In section 3, we show model results on the spatial distribution and properties of the dense flows and the results on the mean pathways, transformation, and transit times. The summary and discussion are given in section 4 .

\section{Methods}

We describe here the numerical model, as well as the integration technique that we use to simulate Lagrangian particles using the model fields.

\section{a. Numerical model}

We employ a hydrostatic version of the Massachusetts Institute of Technology General Circulation Model configured for the Irminger Basin. The model setup is identical to that of Magaldi et al. (2011) except that it has increased vertical resolution (see below). The model simulates summer 2003 (1 July-31 August). As the overflow transport and properties throughout the Irminger Basin show little variation at seasonal time scales (see the introduction), this period resolves the primary variability of the overflow. In fact, Dickson and Brown (1994) verified that the overflow diagnostics at the Angmagssalik section converge in about one month. Also, Haine et al. (2009) found that the dense water flux in the Denmark Strait is controlled by the internal ocean dynamics rather than the seasonally modulated atmospheric forcing. The interannual variations of dense overflows have been addressed elsewhere (Köhl 2010; Serra et al. 2010). Our configuration focuses on the high spatial resolution needed to resolve the processes controlling the dominant variability (Haine et al. 2009).

The model uses partial bottom cells and a rescaled height coordinate to accurately simulate flows over steep topography (Adcroft and Campin 2004). It also features a nonlinear free surface, a flow-dependent Leith biharmonic viscosity, and a third-order advection scheme with zero explicit diffusivity for tracers. The $K$-profile parameterization (Large et al. 1994) is used with a background vertical viscosity of $10^{-5} \mathrm{~m}^{2} \mathrm{~s}^{-1}$. The equation of state is according to Jackett and McDougall (1995). There are three open boundaries (north, east, and south); the west boundary is closed at the east coast of Greenland. The boundary conditions for tracers and velocities are obtained from the $1 / 12^{\circ}$-resolution North Atlantic nontidal experiment of the Hybrid Coordinate Ocean Model (Chassignet et al. 2009). No-slip conditions are applied to all material boundaries. For the wind stress, we use the composite SeaWinds product [Zhang et al. (2006), resolution $0.25^{\circ}$ ]. Other atmospheric variables used to force the model are derived from the National Centers for Environmental Prediction 6-hourly reanalysis (Kalnay et al. 1996).

The model has a nominal horizontal spacing of $2 \mathrm{~km}$. The only change with respect to the setup of Magaldi et al. (2011) is increased vertical resolution, from 97 to 210 levels, with gridcell height ranging from $2 \mathrm{~m}$ at the surface to $15 \mathrm{~m}$ at depths greater than $100 \mathrm{~m}$. This change improves the simulation of the overflow occupying the 1000-2000-mdepth range in the Irminger Basin (the vertical grid size is reduced from 100 to $15 \mathrm{~m}$ at these depths). To our knowledge, this is the highest-resolution ocean model configuration of the overflow into the Irminger Basin to date.

\section{b. Integration of synthetic Lagrangian particles}

The numerical particles are simulated offline using output velocity fields from the model. The deployment strategy is discussed in the next section, following the presentation of the model results regarding the dense water masses. Here, we focus on the technical aspects of the integration. The particles are fully Lagrangian, that 
is, they move in three dimensions. There is no explicit diffusion in the particle code as we assume that all the information about the flow is contained in the model velocity field. For the particle code, we employ the matrix laboratory (MATLAB) software. The particles are advanced using ode23t, a trapezoidal solver with a second-order predictor and third-order corrector scheme. ${ }^{3}$ The relative tolerance is set to $10^{-6}$, the absolute horizontal and vertical tolerance values are $1 \mathrm{~m}$ and $1 / 10$ of the vertical grid height at the instantaneous particle position. At each time step $i$, the model velocities at $i$ and $i+1$ are linearly interpolated on particle positions and passed to the MATLAB solver. We conducted a sensitivity study and found that a time step $d t=15 \mathrm{~min}$ is sufficient to resolve the variability of the model velocity field (which is dominated by dense boluses cascading over bathymetric slopes and associated internal waves). ${ }^{4}$ For the boundary conditions, the velocity component normal to the boundary is zero and the particles slide along the bottom and walls of the domain. The particle trajectories terminate upon reaching $62^{\circ}$ and $69^{\circ}$ latitude (the meridional boundaries of the numerical model are at $60^{\circ}$ and $70^{\circ}$ latitude, but we narrow this range to avoid sponge layer effects at open boundaries). The code is available from the corresponding author.

Once the particle trajectory integration is completed, time series of temperature and salinity are obtained by linear interpolation from the model property fields onto particle trajectories at each time step using the zero gradient condition at the boundary. The model equation of state (Jackett and McDougall 1995) is then used to compute the density.

\section{Results}

\section{a. Dense circulation in the numerical model and comparison with data}

To evaluate the model realism and give context for the particle deployment strategy, we first present Eulerian

\footnotetext{
${ }^{3}$ We tested ode 45 , ode $15 \mathrm{~s}$, ode113, ode23t, and ode $23 \mathrm{bt}$ from the MATLAB suite. Considering particle displacement statistics, the differences between the solvers were insignificant. The fastest solver for this problem was ode23t.

${ }^{4}$ The sensitivity study relied on simulating a cluster of 81 particles released at the Denmark Strait sill. We varied the time step and inspected the mean horizontal and vertical positions, velocity distributions, spectra and autocorrelations, and travel times to the Angmagssalik section. The horizontal velocity and travel time statistics converged at $d t=0.25$ day, but the vertical position statistics required $d t=15 \mathrm{~min}$ to do so. This time step resolves the Lagrangian decorrelation scale, which is $\sim 1$ day and $\sim 0.25$ day for horizontal and vertical components, respectively.
}

results on the dense water flows. We define the dense waters by $\sigma_{\theta} \geq 27.8$ (e.g., Dickson and Brown 1994; Tanhua et al. 2005). Figure 1a shows a map of the frequency of occurrence of dense water during the twomonth simulation. ${ }^{5}$ The depth-averaged current vectors in the $\sigma_{\theta} \geq 27.8$ layer are superimposed. Dense waters are recorded continuously in the central Irminger Basin and the Denmark Strait and stretch on the East Greenland Shelf (EGS) as far as $200 \mathrm{~km}$ south of the strait. The fastest dense flow traces the conventional DSO over the sill and south along the continental slope. The mean speeds of this plume reach $1 \mathrm{~m} \mathrm{~s}^{-1}$ at the sill and $\sim 0.5 \mathrm{~m} \mathrm{~s}^{-1}$ downstream.

The positions of major hydrographic and mooring sections focused on the DSO are marked with red lines in Fig. 1a. The hydrographic section at the Denmark Strait sill is centered at $66^{\circ}$ latitude, $-28^{\circ}$ longitude (Girton and Sanford 2003; Macrander et al. 2007). Approximately $300 \mathrm{~km}$ downstream along the continental slope is the Spill Jet section $\left(65^{\circ}\right.$ latitude, $-33^{\circ}$ longitude; Pickart et al. 2005). Another $300 \mathrm{~km}$ along the slope, the Angmagssalik array (ANGM) is moored ( $63^{\circ}$ latitude, $-36^{\circ}$ longitude; Dickson et al. 2008; Hall et al. 2011). Note that the model dense waters extend northwest of the sill on the shelf, consistent with observations (Macrander et al. 2007; Brearley et al. 2012). Also, as reported in observations (Rudels et al. 2002), dense waters fill the 650-m-deep Kangerdlugssuaq Trough that cuts the strait and shoals gradually toward the shelf break near the SJ section. The flow in the trough is cyclonic and can potentially drain dense water toward the shelf break. On the Dohrn Bank, there is an anticyclonic recirculation that facilitates the transfer between the trough and the sill and redistributes dense waters on the shelf.

We report the model volume transports first. Magaldi et al. (2011) analyzed the same model configuration but with lower vertical resolution. They found that the dense water transports at Denmark Strait sill $(-2.9 \pm 1.7 \mathrm{~Sv}$ for $\left.\sigma_{\theta} \geq 27.8\right)$ and the SJ section $(-6.1 \pm 2.8 \mathrm{~Sv})$ are consistent with observations [Jochumsen et al. (2012) and Pickart et al. (2005), negative transports are equatorward]. ${ }^{6}$ This agreement holds for the 210-level run $(-3.0 \pm 1.8$ and $-5.4 \pm 3.0 \mathrm{~Sv}$ for the DS sill and the SJ sections, respectively). The volume transport at Angmagssalik section is highly variable, but the 2-month average for the overflow core $\left(\sigma_{\theta} \geq 27.85\right)$ and for the entire line of moorings is $-4.2 \pm 2.3 \mathrm{~Sv}$, which matches

\footnotetext{
${ }^{5}$ Figure 1 of Magaldi et al. (2011) shows the full domain. All of the figures here only display the central area of interest.

${ }^{6} \mathrm{Plus} / \mathrm{minus}$ bounds indicate the standard deviations of transport time series and are measurements of model transport variability.
} 
a)

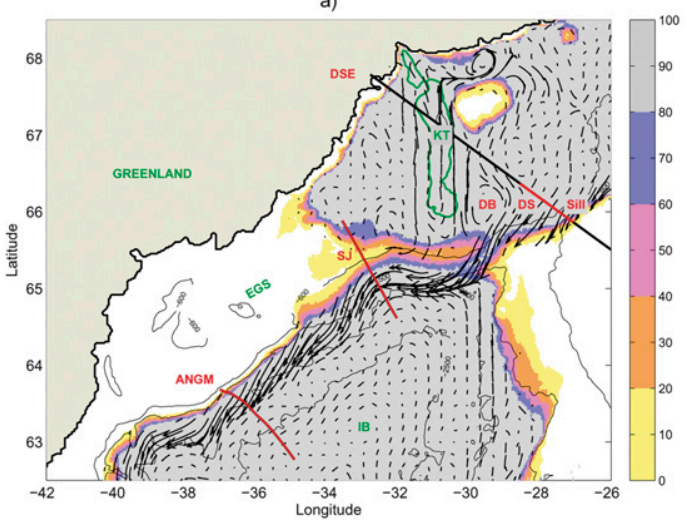

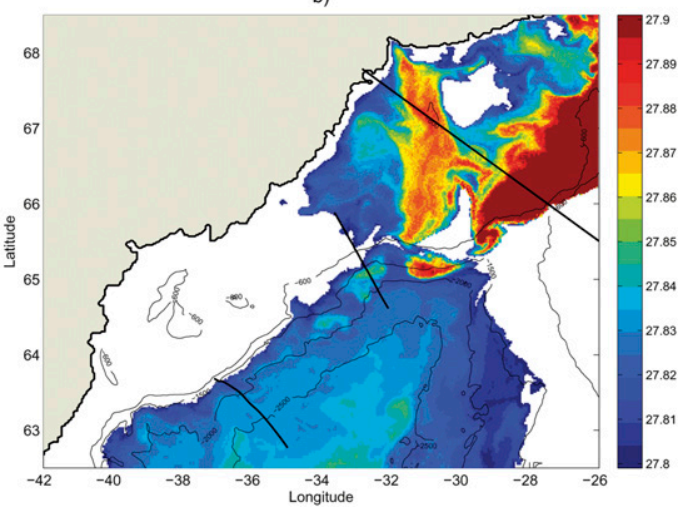

FIG. 1. Dense water in the DS/EGS/IB model. For clarity, only a subset of the model domain is shown. (a) Occurrence frequency $(\%)$ of dense waters $\left(\sigma_{\theta} \geq 27.8\right)$ during the 57-days run at any depth. The time- and depthaveraged dense $\left(\sigma_{\theta} \geq 27.8\right)$-current vectors are plotted where dense water exists in at least two vertical grid points for at least 36 days. The DSE section is plotted with a black line, and the traditional DS sill section is plotted with a red line. The SJ and the ANGM sections are indicated by red lines. The DB is also marked. The KT is outlined with the 450-m isobath in green. The 600-, 1500-, 2000-, and 2500-m isobaths are superimposed. (b) Snapshot of the depthaveraged density in the $\sigma_{\theta} \geq 27.8$ layer on 2 Aug 2003 .

well with the observations [ $4 \mathrm{~Sv}$ per Dickson et al. (2008), their Table 19.2]. For $\sigma_{\theta} \geq 27.8$, the model volume transport is $-7.2 \pm 2.0 \mathrm{~Sv}$, indistinguishable from $-7.3 \mathrm{~Sv}$ in observations. This consistency builds confidence that the modeled dense water transport processes are realistic.

We also verify that the model reproduces the hydrographic structure and variability of the overflow at the Denmark Strait and downstream. The dense waters cascade from the Denmark Strait sill at 2-5-day intervals in the form of 30-50-km-wide dense water boluses. The descent of model boluses leaving the sill is shown by Magaldi et al. (2011, their Fig. 5), replicating the observations from Käse et al. (2003). Figure $1 \mathrm{~b}$ further visualizes the mesoscale variability at the Strait in a snapshot of the depth-averaged density field for model points satisfying $\sigma_{\theta} \geq 27.8$. Four boluses are visible: one is forming from the dense water wedge just to the north of the sill, one is cascading down the sill, one is crossing the SJ section, and one is $100 \mathrm{~km}$ farther downstream. These two last boluses are $0.05 \mathrm{~kg} \mathrm{~m}^{-3}$ lighter than the one cascading over the sill, implying that strong mixing has taken place between the sill and the SJ section. Farther south, the boluses gradually disappear and are hardly recognizable in the density field at the Angmagssalik array. The boluses follow the isobaths of the continental slope and form, on average, the path of the time-mean plume (Käse et al. 2003) visible in Fig. 1a. An intense water mass exchange also occurs on the Dohrn Bank ( $65.5^{\circ}$ latitude, $-30^{\circ}$ longitude $)$, mediated by the anticyclonic circulation visible in the mean current field in Fig. 1a. This exchange supplies the very dense $\left(\sigma_{\theta} \geq\right.$
27.88) waters from the sill to the Kangerdlugssuaq Trough. Finally, there is a spilling event in Fig. 1b at the shelf break where the dense waters from the Kangerdlugssuaq Trough connect with a passing bolus.

The conventional Denmark Strait sill section misses much of the dense water spread over the strait. Therefore, we extend the section toward the coast to capture the entire dense water layer and refer to it as the extended Denmark Strait section (DSE; marked in Fig. 1a). A snapshot of density along this section is shown in Fig. 2a. It shows a dense water bolus passing through the sill on 4 July. The densest fraction $\left(\sigma_{\theta} \geq 27.9\right)$ resides at the bottom of the Kangerdlugssuaq Trough and in the sill. The dense bolus is banked against the western flank of the sill and there is a sharp front to the east associated with an inflow of lighter Atlantic water in the Irminger Current (Magaldi et al. 2011). This circulation pattern (a dense outflow on the western flank and a light inflow on the eastern side) is consistent with a theoretical solution for a rotating, hydraulically controlled flow in a sill that is wider than the Rossby radius (Whitehead et al. 1974; Käse and Oschlies 2000), and is also corroborated by observations (e.g., Girton et al. 2001; Macrander et al. 2007).

The potential temperature $\theta$-salinity $S$ diagram corresponding to Fig. 2a appears in Fig. 2b and is color coded by position on the section. The densest $\left(\sigma_{\theta}>28\right)$ waters fill the bottom of the sill. However, for $\sigma_{\theta}<27.9$, the water in the sill, on the shelf, and in the Kangerdlugssuaq Trough are indistinct in $\theta-S$ space. The dense overflow is composed of Arctic Atlantic Water (AAW) and Recirculating Atlantic Water (RAW), which are characterized 
a)

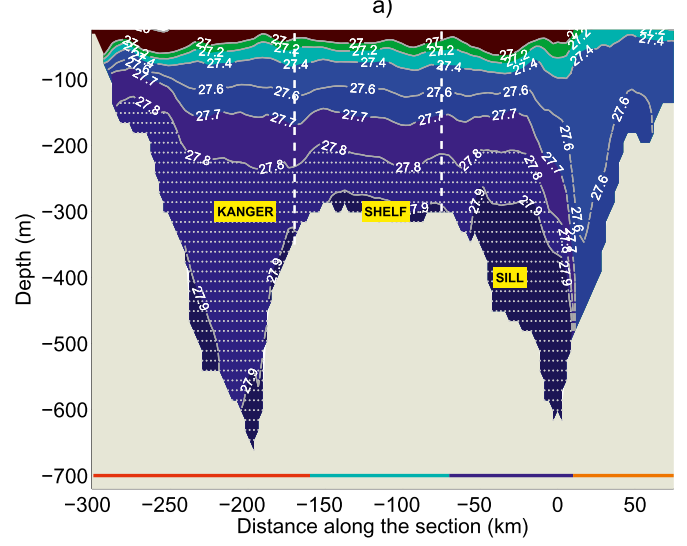

b)

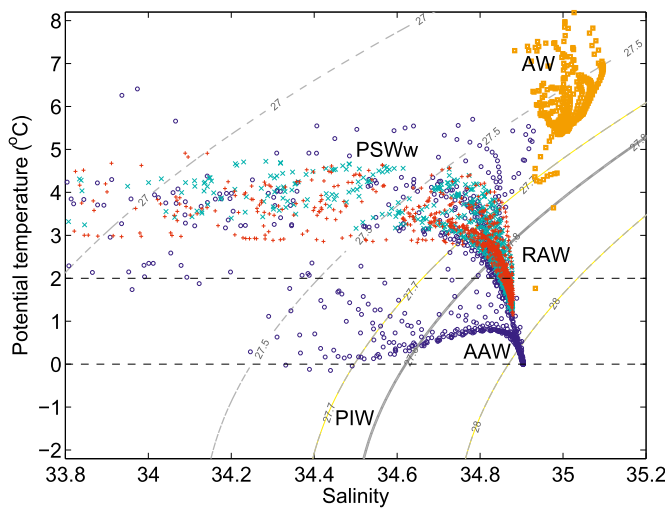

FIG. 2. Water masses at the DSE section. (a) Density on 4 Jul 2003, seen from the south. The distance along the section is calculated with the origin at the deepest location of the DS sill $\left(66.0^{\circ}\right.$ latitude, $-27.4^{\circ}$ longitude). Deployment locations of the three particle groups (KANGER, SHELF, and SILL) are indicated with white dots, the white-dashed lines separate the groups. (b) Corresponding $\theta\left({ }^{\circ} \mathrm{C}\right)-S$ diagram, color coded by the along-section distance [the key to the distance markers is included at the bottom of (a)]. The $\sigma_{\theta}=27.8$ isopycnal is marked with a thick line. The following water masses are indicated (Rudels et al. 2002): AW, RAW, AAW, PIW, and PSWw. The dotted lines separate the PIW from AAW $\left(0^{\circ} \mathrm{C}\right.$ isotherm $)$ and $\mathrm{AAW}$ from RAW $\left(2^{\circ} \mathrm{C}\right.$ isotherm).

by $27.70<\sigma_{\theta} \leq 27.97$, and are colder and warmer than $2^{\circ} \mathrm{C}$, respectively (Rudels et al. 2002). Some of the water lies on a mixing line between AAW and Polar Intermediate Water (PIW; $\sigma_{\theta}>27.7$ and $\theta<0^{\circ} \mathrm{C}$ ); it corresponds to a fresh, cold lid capping the dense bolus (visible in $\theta$ and $S$ sections not shown here). These fresh lenses have been observed by Rudels et al. (1999), and the model properties follow their L3 station where the fresh lens was observed (their Fig. 2d). The warm $(\theta \geq$ $\left.5^{\circ} \mathrm{C}\right)$ and saline water closer to Iceland is the Atlantic Water (AW) of the Irminger Current. The dense waters on the shelf and in the Kangerdlugssuaq Trough are overlaid by fresher "warm" Polar Surface Water (PSWw). The model $\theta-S$ samples indicate intense diapycnal mixing of the dense waters and PSWw, consistent with hydrography (Rudels et al. 2002; Tanhua et al. 2005). There are also signs of mixing with AW in the Irminger Current. From Figs. 1a and 1b, as well as horizontal snapshots of $\theta$ and $S$ (not shown), we deduce that the mixing is due to recirculation on the shelf that involves dense waters, fresh polar waters, and warm and salty Irminger Current water, some of which penetrates onto the shelf. These isolated Irminger Current lenses on the shelf in Denmark Strait have been repeatedly observed (Rudels et al. 2002; Brearley et al. 2012).

Between boluses, the volume of dense water in the sill decreases and the height of the plume reduces from 300 to $20-50 \mathrm{~m}$, consistent with observations (Bruce 1995; Käse et al. 2003). The cold, freshwater $\left(\theta<1^{\circ} \mathrm{C}\right.$ and $S<$ $34.9)$ is then absent from the $\theta-S$ diagram and the front lies $50 \mathrm{~km}$ closer to the shelf. This westward front migration during low-overflow events has been observed by Rudels et al. (1999). The dense waters in the Kangerdlugssuaq Trough and on the shelf, on the other hand, exhibit much less temporal variability.

At the SJ section, our simulation replicates the results of Magaldi et al. (2011) faithfully representing the observed hydrography. At the Angmagssalik section, the overflow core [identified by $\sigma_{\theta} \geq 27.85$ and the salinity minimum, see Dickson et al. (2008)] is centered at the 2300-m isobath. It has a mean salinity of 34.9 and a mean temperature of $2.5^{\circ} \mathrm{C}$, slightly higher than the long-term means from the moorings. However, the year 2003 was particularly warm and saline [Dickson et al. (2008), their Figs. 19.11 and 19.12; see also Yashayaev and Dickson (2008)]. The model property time series at Angmagssalik (not shown) vary on longer time scales (3-10 days) than at the sill, consistent with the observations of Voet and Quadfasel (2010). This fact reflects the overflow boluses becoming less pronounced in the density field (Fig. 1b).

\section{b. Particle deployments at the Denmark Strait}

To resolve the cycle of volume transport variability at DS sill due to boluses [2-5-day period, e.g., Girton and Sanford (2003) and Macrander et al. (2007)], particles are released every $12 \mathrm{~h}$ for 5 days starting 1 July 2003 . This schedule samples the dominant volume transport variability [see Fig. 6 of Magaldi et al. (2011), which is consistent with the observations of Dickson et al. (2008)]: the first 2.5 days correspond to low flow through the sill and the second 2.5 days capture the passage of 

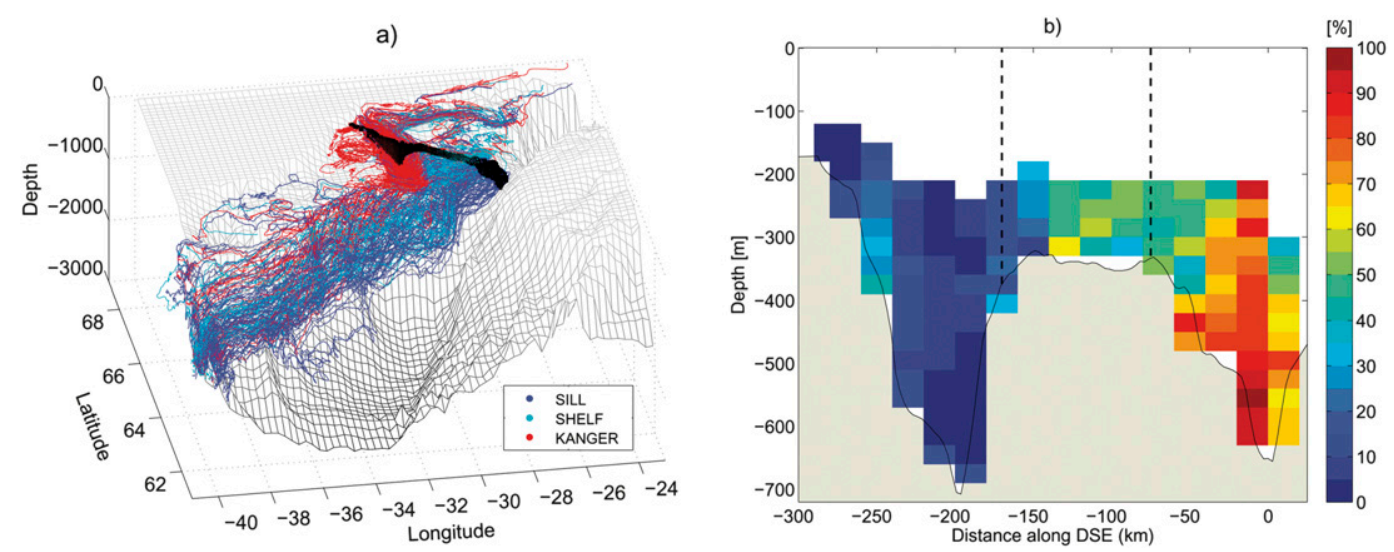

FIG. 3. Particle trajectories from the DS. (a) Trajectories color coded by deployment subset (blue, cyan, and red mark SILL, SHELF, and KANGER particles, respectively). For clarity, only every 30th particle is shown. (b) Particles that reached $62^{\circ}$ lat within 57 days (\%), projected on the initial position along the DSE section. The distributions were calculated in $20 \mathrm{~km} \times 30 \mathrm{~m}$ bins. The black-dashed lines separate the particle deployment groups.

a dense water bolus. The particle initial positions are separated by $2 \mathrm{~km}$ in the horizontal and $25 \mathrm{~m}$ in the vertical directions and all particles initially have $\sigma_{\theta} \geq$ 27.8. There are 11813 particles in total. Each set of particles is advanced for 57 days to ensure the same time series length. We analyze all of the particles together, thus averaging over the variability at the sill. The particles are classified into three subsets according to their initial position $d_{o}$ along the DSE section with the origin $d_{o}=0$ at the bottom of the sill and negative and positive distances in the northwest and southeast directions, respectively (see Fig. 2a).

- Particles deployed at the Denmark Strait sill $\left(d_{o}>\right.$ $-70 \mathrm{~km}$ ) correspond to the conventional overflow (SILL, 3301 particles), which has received most of the observational focus.

- Particles deployed on the adjacent shelf: $d_{o}$ between -160 and $-70 \mathrm{~km}$ along the section, depth shallower than $-320 \mathrm{~m}$ (SHELF, 1827 particles).

- Particles deployed in the Kangerdlugssuaq Trough, $d<-160 \mathrm{~km}$ (KANGER, 6685 particles).

Note that the SILL subset, which tracks the conventional DSO, contains only $28 \%$ of the dense waters across the DSE, while KANGER and SHELF fractions add $56 \%$ and $16 \%$, respectively. In terms of volume transport, the mean southward transport attributable to the particles (the product of the particle speed perpendicular to the section and the cross-sectional area of the model grid cell) is $2 \mathrm{~Sv}$. The contribution of the SILL particles to the volume transport over the 5-day deployment period is $94 \%$ (varying between 1 and $3.2 \mathrm{~Sv}$ ). The SHELF and KANGER particles are moving in both directions across the section because of flow reversals associated with the recirculations. Their average contributions to the volume transport are $4 \%$ and $2 \%$, respectively.

We refer to the part of the Denmark Strait to the northwest of the sill, encompassing the shelf adjacent to the sill and the Kangerdlugssuaq Trough, as the "continental shelf."

\section{c. Particle trajectories-A general description}

Trajectories are shown in Fig. 3a and are color coded by the initial distance along the section. Animations of particle evolution, in a horizontal and three-dimensional view are accessible as supplemental material at the Journals Online website. Weekly snapshots of the particle positions are shown in Fig. 4. The preferred pathways are shown in Fig. 5a.

The particles reveal the complexity of the pathways of dense water from Denmark Strait. They clearly depict the "conventional" route along the East Greenland shelf break. But the trajectories on the shelf part of the strait trace multiple recirculations and some of them spill off the shelf and contribute to the along-slope flow. During the 2-month integration, 3737 particles (32\% of the total deployment) reach $62^{\circ} \mathrm{N}$. Of these, $61 \%$ were deployed at DS sill (SILL particles), $24 \%$ at the SHELF, and $15 \%$ at KANGER (Table 1). Over one-half of the particles (6906 or $59 \%$ ) stays within $200 \mathrm{~km}$ of their release position. The majority of these $(78 \%)$ are deployed in the Kangerdlugssuaq Trough. Only five particles reach $69^{\circ}$ latitude and all are from the KANGER group. We now look at the evolution of particles released in different locations along the DSE section.

The SILL particles (blue trajectories in Fig. 3a, blue dots in the animations accessible as supplemental material 

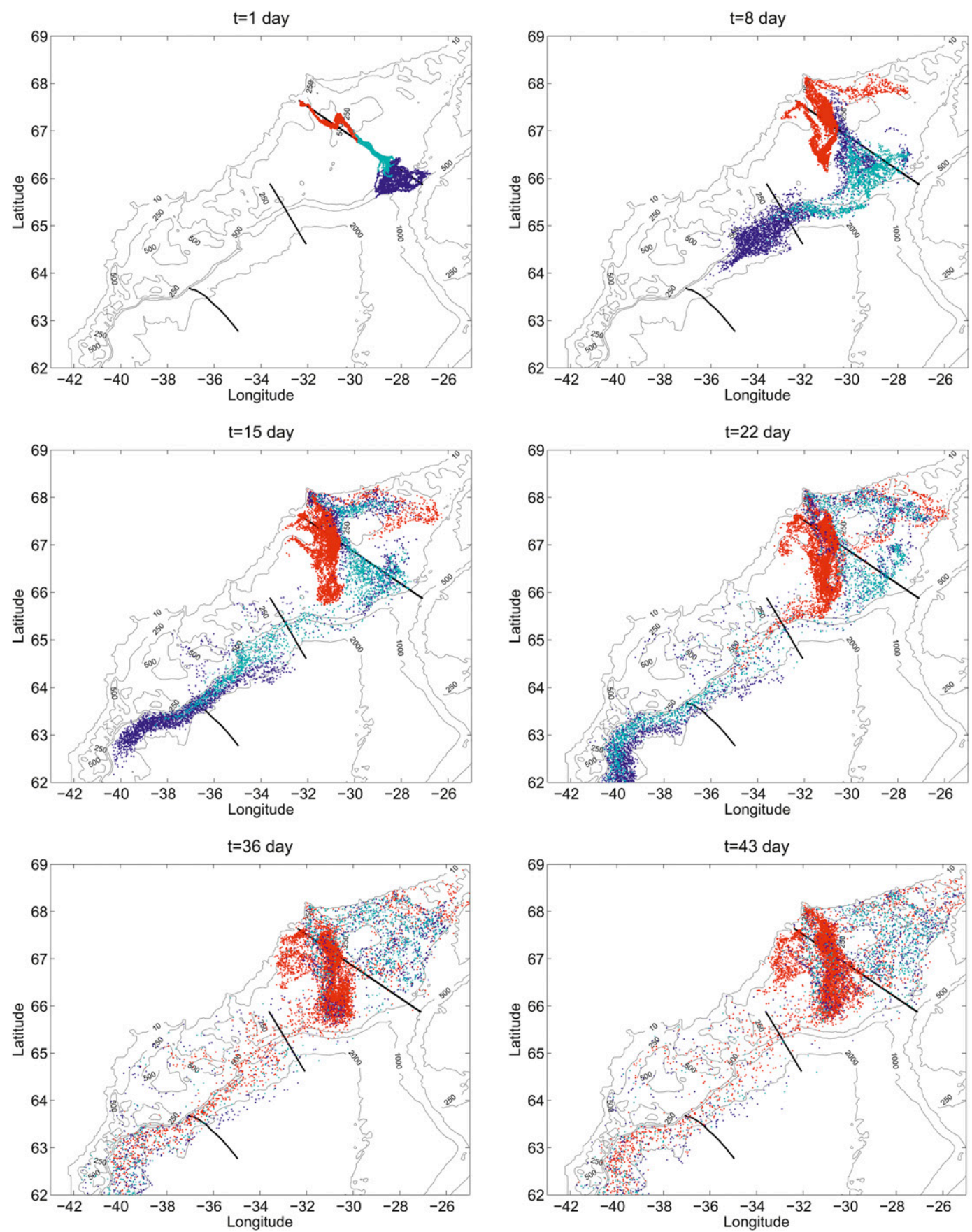

FIG. 4. A sequence of particle positions at days 1, 8, 15, 22, 36, and 43 of the simulation projected onto the horizontal plane (colors as in Fig. 3). See also the animations in the supplemental material at the Journals Online website (http://dx.doi.org/10.1175/JPO-D-13-023s1.txt, http://dx.doi.org/10.1175/JPO-D-13-023s2.m4v, and http://dx. doi.org/10.1175/JPO-D-13-023s3.m4v).

at the Journals Online website and in Fig. 4, and the bottom right panel in Fig. 5a) show two distinct behaviors. The majority (69\%) cascade over the sill, follow the shelf break southward (the conventional route), and reach $62^{\circ}$ latitude within the integration period. The particles released in the core of a dense bolus in the deepest part of the sill have the highest exit rate (nearly $100 \%$; Fig. 3b). Some of them cascade to the sea floor and proceed as a dense water plume, others occupy shallower depths as intermediate waters, implying that 


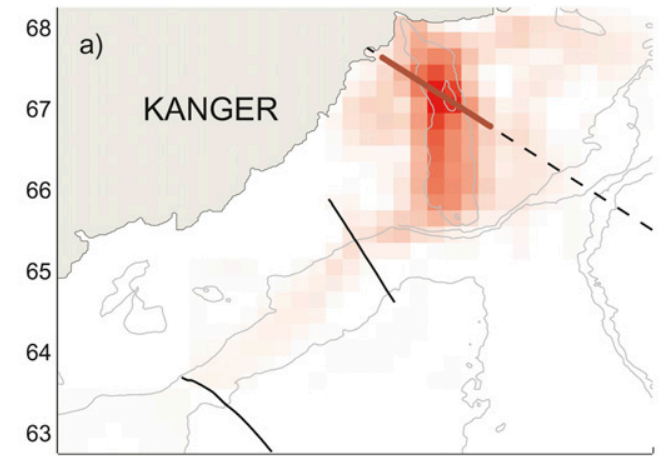

Fraction deployed
\begin{tabular}{|cccccc}
\hline & $\vdots$ & $\vdots$ & & \\
0 & 0.1 & 0.2 & 0.3 & 0.4 & 0.5 \\
\hline 0 & $\vdots$ & $\vdots$ & & \\
\hline & 0.1 & 0.2 & 0.3 & 0.4 & 0.5 \\
\hline & $\vdots$ & $\vdots$ & $\vdots$ & & \\
0 & 0.1 & 0.2 & 0.3 & 0.4 & 0.5
\end{tabular}
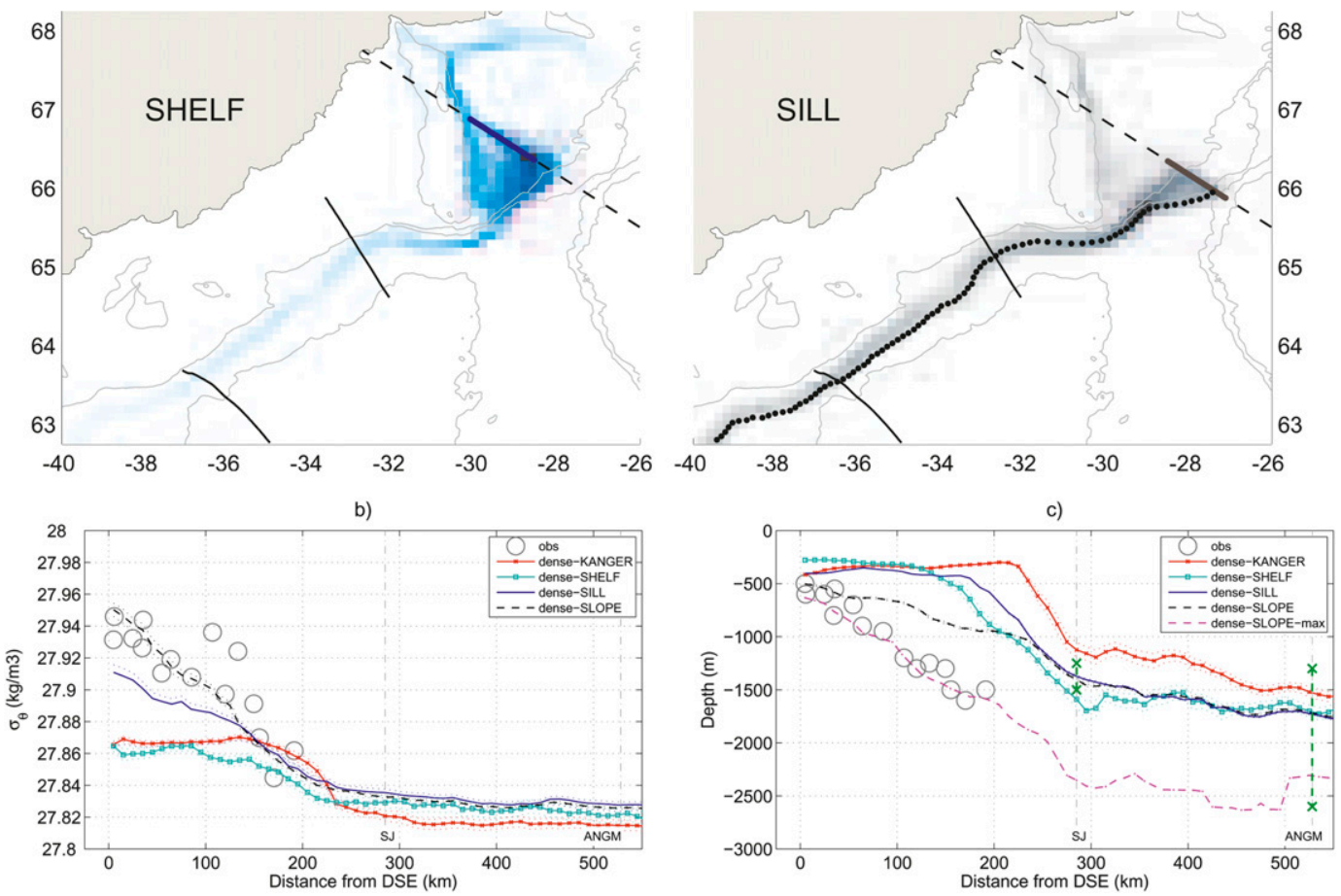

FIG. 5. (a) Pathways of the dense water deployed at the DS. The shading shows the fraction, at each place, of the total number of particles for the given set that visits that place during the 60-day simulation. Only dense particles $\left(\sigma_{\theta} \geq 27.8\right)$ are considered. In the SILL panel, black dots mark the mean path of SLOPE particles (see text). (b) Evolution of ensemble-mean particle density with distance from the sill. Superimposed with circles are the hydrographic observations from Girton and Sanford (2003). (c) Evolution of ensemble-mean particle vertical position with distance from the sill. The pink line marks the max depths of the SLOPE particles. The green lines at the SJ and Angmagssalik sections depict depth ranges for DSO from Brearley et al. (2012, their Fig. 6) and Dickson et al. (2008, their Fig. 19.6). In (b),(c), the geographical distance from the particle release point is used. The results of Girton and Sanford (2003) were shifted from their reference point to match the ensemble-mean release position of the SLOPE particles at the deployment.

water mass modification occurred along their trajectories (see section 3e). Some 178 particles ascend up onto the continental shelf for at least 1 day. Most of these particles enter the shelf near a deflection in the $500-\mathrm{m}$ isobath $\left(65^{\circ}\right.$ latitude, $-34^{\circ}$ longitude; see the animation in the supplemental material at the Journals Online website at http://dx.doi.org/10.1175/JPO-D-13-023s1.txt and http://dx.doi.org/10.1175/JPO-D-13-023s2.m4v) that probably destabilizes the along-isobath flow. Almost one- quarter of the SILL particles (22\%) get swept by the anticyclonic recirculation on the Dohrn Bank and directed into the Kangerdlugssuaq Trough and are still found within $200 \mathrm{~km}$ of the release site at the end of the simulation (Table 1).

About half of the SHELF particles (cyan trajectories in Fig. 3a, cyan dots in animations and in Fig. 4, bottom left panel in Fig. 5a), after looping for about a week in the anticyclonic recirculation on the Dohrn Bank (see 
TABLE 1. Particle position statistics for the whole dataset (ALL) and each of three subsets (SILL, SHELF, and KANGER; see text). No. is the total number of particles; Exit is the number of particles that exit at $62^{\circ}$ lat during the 8-week simulation; North-DSE is the number of particles that are north of the DSE section after the 8 -week simulation; $200 \mathrm{~km}$-DSE is the number of particles located within $200 \mathrm{~km}$ of the DSE section after the simulation; No. (shelf) is the number of particles present on the East Greenland shelf (west of $-34^{\circ}$ lon and water depth $<500 \mathrm{~m}$ ) for at least 1 day during the simulation.

\begin{tabular}{lrrccc}
\hline \hline $\begin{array}{c}\text { Particle } \\
\text { group }\end{array}$ & No. & Exit & North-DSE & 200 km-DSE & $\begin{array}{c}\text { No. } \\
\text { (shelf) }\end{array}$ \\
\hline ALL & 11813 & 3737 & 3756 & 6906 & 401 \\
SILL & 3301 & 2278 & 545 & 736 & 178 \\
SHELF & 1843 & 892 & 623 & 802 & 86 \\
KANGER & 6669 & 567 & 2588 & 5368 & 137 \\
\hline
\end{tabular}

the animations in the supplemental material at the Journals Online website at http://dx.doi.org/10.1175/ JPO-D-13-023s1.txt, http://dx.doi.org/10.1175/JPO-D13-023s2.m4v, and http://dx.doi.org/10.1175/JPO-D-13$023 \mathrm{~s} 3 . \mathrm{m} 4 \mathrm{v}$ ), spill off the shelf break from $-29^{\circ}$ to $-30^{\circ}$ longitude and proceed along the shelf southward. These particles reach $62^{\circ}$ latitude within the simulation period, constituting almost one-quarter of the particles that exit (Table 1). Many particles (44\%) recirculate on the Dohrn Bank and in the Kangerdlugssuaq Trough, and the remainder are en route along the shelf break.

The majority $(81 \%)$ of the KANGER particles (red trajectories in Fig. 3a, red dots in animations available in the supplemental material at the Journals Online website at http://dx.doi.org/10.1175/JPO-D-13-023s1.txt, http:// dx.doi.org/10.1175/JPO-D-13-023s2.m4v, http://dx.doi.org/ 10.1175/JPO-D-13-023s3.m4v, http://dx.doi.org/10.1175/ JPO-D-13-023s4.m4v, and http://dx.doi.org/10.1175/JPOD-13-023s5.m4v and in Fig. 4, upper panel in Fig. 5a) recirculate in the Denmark Strait and are found there at the end of the simulation (see also Fig. 3b). The remaining particles are carried by the cyclonic flow in the Kangerdlugssuaq Trough toward the shelf break and spill into the Irminger Basin near the SJ section. The first spilling of KANGER particles, deployed on the western flank of the trough, and thus advected directly toward the shelf, occurs approximately 3 weeks after the deployment. This provides an estimate of the half-recirculation period in the trough (see section 3f). The spilled particles join the dense flow along the slope and eventually exit at $62^{\circ}$ latitude. The particles released at the western flank of the trough have a higher $(\sim 40 \%)$ exit rate because the cyclonic circulation in the trough carries them directly toward the shelf break thus facilitating their spilling (Fig. 3b). During the 2-month record, the KANGER particles comprise $15 \%$ of the total particle exits at $62^{\circ}$ latitude (Table 1 ).
TABLE 2. Transit time statistics from the DS to the SJ and Angmagssalik sections. No. is the number of particles recorded; $\mathcal{M}$ (days) is the modal particle transit time; and $\langle\tau\rangle$ is the mean particle transit time from the 57-day long trajectories. The standard error quantifies the uncertainty on $\langle\tau\rangle .\langle\tau\rangle_{\infty}$ is the mean transit time estimate obtained by extrapolating the tails of the particle transit time distributions. The values $\langle\tau\rangle_{\infty}$ for KANGER particles and ALL particles are not listed because extrapolation is too uncertain (see text). No. dense is the number of dense $\left(\sigma_{\theta} \geq 27.8\right)$ particles recorded.

\begin{tabular}{llrrrrr}
\hline \hline \multirow{1}{c}{ Section } & Particles & No. & $\mathcal{M}$ & \multicolumn{1}{c}{$\langle\tau\rangle$} & $\langle\tau\rangle_{\infty}$ & $\begin{array}{c}\text { Nonse } \\
\text { dense }\end{array}$ \\
\hline Spill Jet & ALL & 4684 & 5 & $16.9 \pm 0.2$ & - & 2245 \\
& SILL & 2532 & 5 & $9.0 \pm 0.2$ & 9.3 & 1481 \\
& SHELF & 1021 & 11 & $16.6 \pm 0.3$ & 17.7 & 391 \\
& KANGER & 1131 & 23 & $34.8 \pm 0.3$ & - & 373 \\
Angmagssalik & ALL & 4032 & 14 & $22.4 \pm 0.2$ & - & 1215 \\
& SILL & 2321 & 13 & $16.4 \pm 0.2$ & 16.9 & 910 \\
& SHELF & 918 & 18 & $22.9 \pm 0.3$ & 23.8 & 193 \\
& KANGER & 793 & 36 & $39.3 \pm 0.3$ & - & 112 \\
\hline
\end{tabular}

The contribution of continental shelf particles to the dense water particles at the downstream sections (No. dense) are summarized in Table 2. Overall, these KANGER and SHELF particles supply almost $35 \%$ of the particles at the SJ section (17\% each). At the Angmagssalik array, $300 \mathrm{~km}$ farther downstream, KANGER and SHELF particles make up 9\% and 17\% of the dense particles, respectively. Thus, the dense water particles originating on the continental shelf in the Denmark Strait make up a substantial part of the dense particles in the Irminger Basin.

\section{d. Mean evolution south of the Denmark Strait}

We look now at the mean evolution of the particles classified by their release site. We compare the particle statistics to the results of Girton and Sanford (2003). They describe hydrographic observations conducted during two cruises in August 1997 and September 1998 in the first $250 \mathrm{~km}$ downstream from the Denmark Strait sill. These observations are most relevant to our results as the properties of the dense waters in the years 1997/98 and in 2003 were similar in otherwise variable conditions (Yashayaev and Dickson 2008).

To allow comparison with these data that sampled the dense waters on the slope, we also consider dense particles located over a seabed deeper than $600 \mathrm{~m}$. These are called SLOPE particles and the mean pathway of these observations (from averaging in $10-\mathrm{km}$ bins) is shown in Fig. 5a. Figure 5b shows the evolution of the mean potential density on particle subsets with downstream distance. We include observations from Girton and Sanford (2003, their Fig. 10) that should be compared to the SLOPE particles. Their density evolution (Fig. 5b) matches the observations well. There is a small discrepancy of $\sim 0.02 \mathrm{~kg} \mathrm{~m}^{-3}$ at $100 \mathrm{~km}$ from the sill that 
can be attributed to the flow variability. The rapid density decrease at 125-200 km emphasized by Girton and Sanford (2003) is reproduced by the SLOPE particles.

Figure $5 \mathrm{c}$ shows the evolution of the mean vertical position in the same format as Fig. 5b. However, the comparison with Girton and Sanford (2003) is not straightforward. They used an averaging technique that emphasizes the densest waters and is difficult to reproduce here. Weighting the SLOPE particles by their deviation from $\sigma_{\theta}=27.8$ (black dashed curve) yields a depth that is shallower than that of Girton and Sanford (2003). However, focusing on the densest and deepest SLOPE particles gives good agreement (pink line in Fig. $5 \mathrm{c})$. We also plot the positions of the DSO core at the SJ section estimated from Fig. 6 in Brearley et al. (2012), which agree well with our results. Their observations include velocity and allow us to separate the DSO core from the more quiescent dense water filling the central Irminger Basin [Girton and Sanford (2003) use only the density criterion]. Similarly, the range of depths for the $\sigma_{\theta} \geq 27.8$ layer at the Angmagssalik section from Dickson et al. (2008) matches well. This good agreement indicates that the modeled plume is not too buoyant owing to excessive mixing. It also highlights the sensitivity of the DSO depth diagnostic to the criteria used.

Now, consider the unconventional pathways. The SHELF particles begin with a lower average density than the SILL particles (Fig. 5b) but their density decrease is (on average) weaker than the particles released in the sill. This is likely related to the presence of the front in the sill and cross-frontal mixing involving mostly the SILL particles. As a result, at the SJ section the SHELF particles approach the SILL particles in the mean density. On average, the SHELF particles undergo a greater increase in depth and are deeper than the SILL particles at the SJ section. The KANGER particles undergo strong mixing during spilling off the shelf at $150-230 \mathrm{~km}$ [see the next section and Magaldi et al. (2011)]. They become lighter than SILL or SHELF particles (by $0.01 \mathrm{~kg} \mathrm{~m}^{-3}$ ) and remain slightly higher (by 100-200 m) in the water column during their subsequent transit along the shelf break.

Beyond $250 \mathrm{~km}$ from the DSE section, the ensemblemean densities for all the particle subsets remain fairly constant implying that diapycnal mixing with other water masses is weak. This is true also for the temperature and salinity. This result agrees with Voet and Quadfasel (2010) who inferred a small change in the mean temperature downstream of the SJ section based on moorings and hydrographic sections along the slope.

\section{e. Property changes}

Now, consider the property changes along the particle trajectories. Figure 6a shows the time series of the fraction of particles that remain dense $\left(\sigma_{\theta} \geq 27.8\right)$, transform to intermediate $\left(27.7<\sigma_{\theta}<27.8\right)$, and light $\left(\sigma_{\theta} \leq 27.7\right)$ densities. The largest density decrease occurs during the first 20 days when $20 \%$ of the particles experience a drop in density to $\sigma_{\theta} \leq 27.8$. After 20 days, the loss due to exit becomes the dominant reason for the loss of particles from the dense class (Fig. 6a also shows the fraction of particles that reach $62^{\circ}$ latitude). The transformation into the light class is low (5\%) and occurs on the shelf. The statistics for the SILL particles are shown with dashed lines. They transform more than twice as fast as the total deployment $(50 \%$ are transformed within 20 days), which is likely due to intense mixing as the overflow waters cascade over the sill into deep water (Tanhua et al. 2008; Voet and Quadfasel 2010). The SILL group also exits quicker, by following the direct, fast route along the slope.

Figure $6 \mathrm{~b}$ shows locations of strong transformation, that is, particle positions at times when the density tendency on trajectories $\left(D \sigma_{\theta} / D t<-0.025,-0.05\right.$, and $\left.-0.1 \mathrm{~kg} \mathrm{~m}^{-3} \mathrm{day}^{-1}\right)$. The strongest transformation occurs between 50 and $250 \mathrm{~km}$ downstream of the Denmark Strait, with two mixing hot spots. One is centered at ( $66^{\circ}$ latitude, $-29^{\circ}$ longitude), $50-100 \mathrm{~km}$ from the sill. The second is centered at $\left(65.4^{\circ}\right.$ latitude, $-32^{\circ}$ longitude), $50-100 \mathrm{~km}$ northeast of the SJ section. Strong transformation also occurs close to the coast, near the Kangerdlugssuaq Fjord. We assess the nature of the mixing processes from the histograms of $D \theta / D t$ and $D S / D t$ corresponding to the strongest transformation events. Distributions of $D S / D t$ are presented in Fig. $6 c$. The transformation along the slope results from mixing with the modified AW carried by the Irminger Current (both temperature and salinity increase with average tendencies of $2^{\circ} \mathrm{C} \mathrm{day}^{-1}$ and $0.07 \mathrm{day}^{-1}$, respectively). This mixing is consistent with the multiparameter analysis of Tanhua et al. (2008). The transformation near the Kangerdlugssuaq Trough, on the other hand, involves mixing with fresh PSWw $\left(D S / D t<-0.3\right.$ day $^{-1}$; the temperature change is weaker because of a wide range of temperatures in PSWw).

Figure $6 \mathrm{~d}$ shows locations where the density $\sigma_{\theta}$ drops below the 27.8 threshold, namely, where particles obtain intermediate density. Most of the particles transform in the vicinity and downstream of the areas of intense mixing between the sill and the SJ section. The SILL and SHELF particles transform closer to the sill, and KANGER particles transform closer to the SJ section. Particles that transform to intermediate density on the shelf are mainly from the KANGER set.

As a result of transformation, the particles span a wide range of densities at the SJ section. We average $\sigma_{\theta}$ on particles recorded at the section to quantify the 

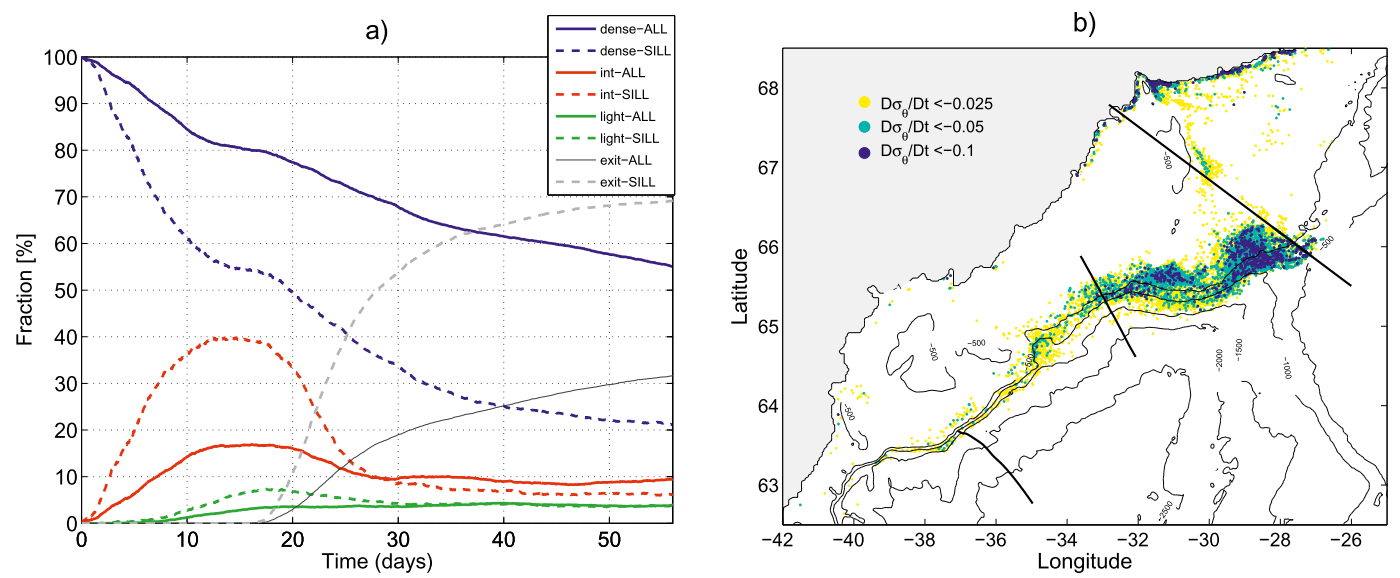

c)
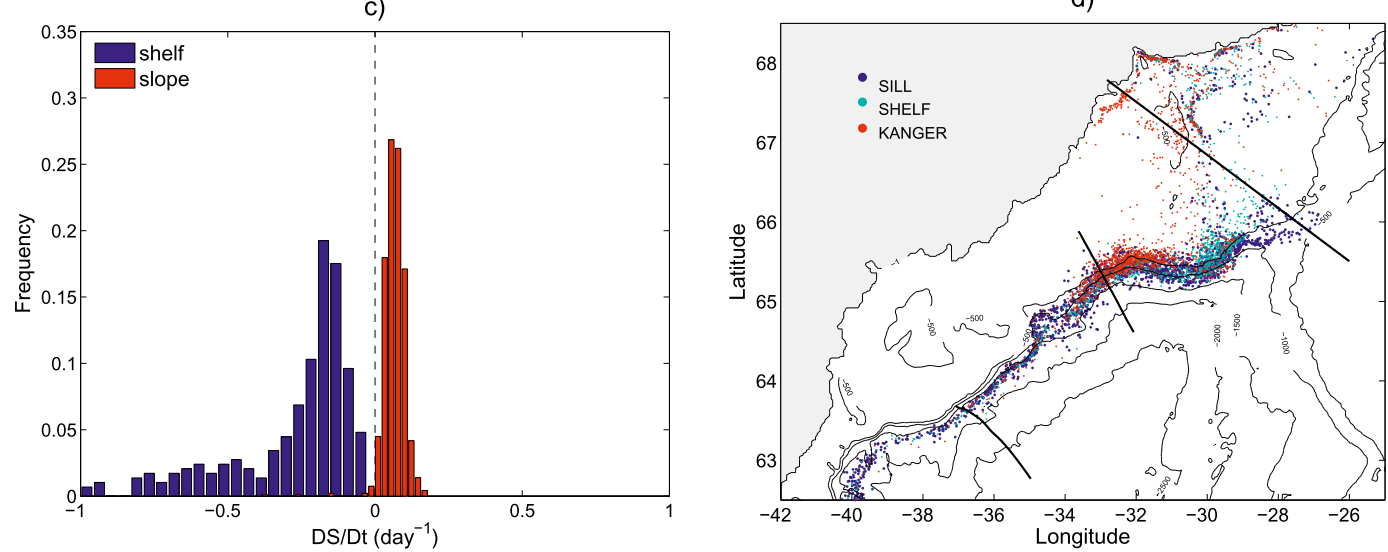

FIG. 6. Water-mass property transformation. (a) Particles in different density classes (\%; relative to the total number of particles deployed) as a function of time: dense $\left(\sigma_{\theta} \geq 27.8\right.$, blue), intermediate $\left(27.7<\sigma_{\theta}<27.8\right.$, red $)$, and light $\left(\sigma_{\theta} \leq 27.7\right.$, green). The gray curve shows the fraction of particles that reaches $62^{\circ}$ lat. The statistics for the SILL subset are shown with dashed lines. (b) Particle positions when potential density transformation rate is high; $D \sigma_{\theta} / D t \leq-0.025,-0.05$, and $-0.1 \mathrm{~kg} \mathrm{~m}^{-3} \mathrm{day}^{-1}$ (yellow, cyan, and blue dots, respectively). (c) Frequency histograms of salinity transformation rate $D S / D t$ from locations of strong density transformation $\left(D \sigma_{\theta} / D t \leq-0.1 \mathrm{~kg} \mathrm{~m}^{-3} \mathrm{day}^{-1}\right)$ on the shelf (blue) and along the continental slope (red). (d) Locations of the transformation from dense to intermediate density (where $\sigma_{\theta}$ first drops below 27.8), color coded by the deployment group. All statistics presented in this figure are derived from 1-day-averaged property time series along particle trajectories.

transformation and to compare the Lagrangian and the Eulerian means. Figure 7a shows mean particle density at the SJ section. The particles occupy a 200-m-thick layer draped over the slope between 200- and 2000-m depths. Although this water originated at the DSE section at $\sigma_{\theta} \geq 27.8$, the densities at the SJ section encompass both dense and intermediate values. Figure $7 \mathrm{~b}$ shows the 60-day Eulerian mean density field from the circulation model, interpolated on nonempty bins in Fig. $7 \mathrm{a}$. The mean particle densities are on average greater than the mean Eulerian densities. The reason is that the particle densities comprise only the contribution from initially dense water, whereas the Eulerian density field also includes the less dense ambient water.
The inset panel in Fig. 7a shows the dominant contributions from SILL, SHELF, and KANGER particles to the DSO at the SJ section. Unsurprisingly, the core of the dense water plume centered at $\sim 1700 \mathrm{~m}$ is formed mainly of SILL particles. However, the SHELF particles dominate the deepest parts of the overflow; they are also the densest. The likely reason is that SHELF particles spill from the DB about $200 \mathrm{~km}$ upstream of the SJ section avoiding strong transformation experienced by the other particles.

\section{f. Transit time statistics}

Next, we focus on the transit-time statistics to the SJ and Angmagssalik sections. Figure 8 shows particle transit time distributions (PTTDs) at the SJ (Fig. 8a) and 
a)

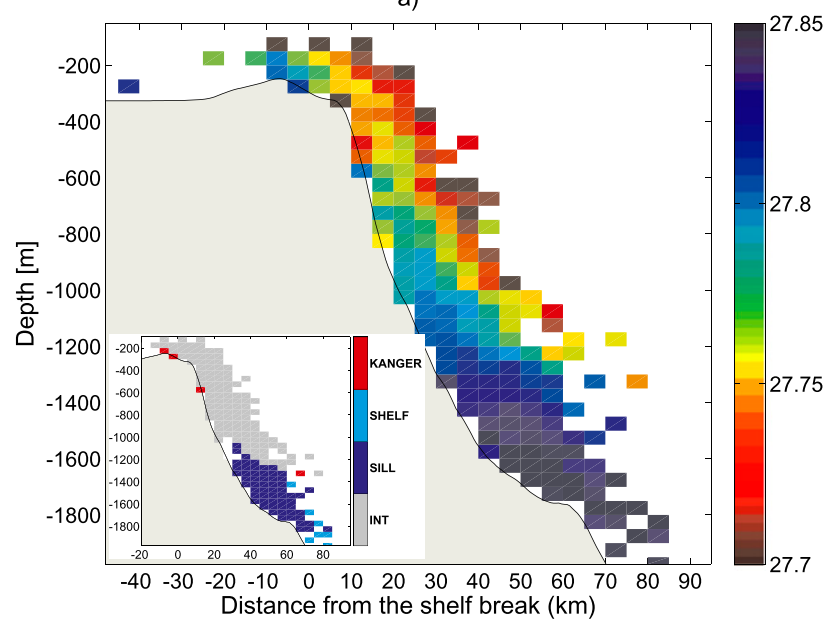

b)

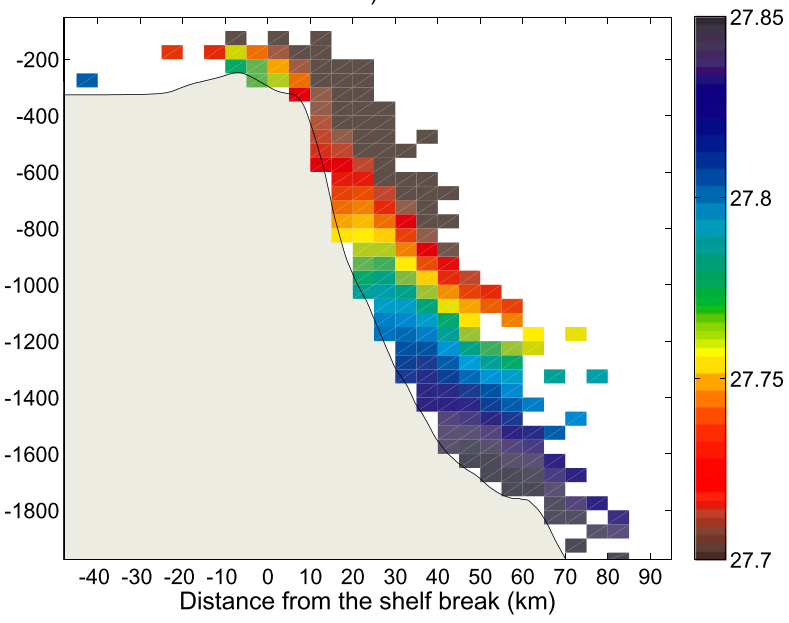

FIG. 7. Density diagnostics at the SJ section. (a) Average $\sigma_{\theta}$ on particles. The inset shows the dominant contributions from different deployment sets to the bins with average $\sigma_{\theta} \geq 27.8$. Bins with the average $\sigma_{\theta}<27.8$ are gray. (b) Eulerian-average $\sigma_{\theta}$ from the numerical model.

Angmagssalik (Fig. 8b) sections. ${ }^{7}$ The number of particles arriving at the two sections, the modal transit times, and the mean transit times are listed in Table 2. Because some particles do not reach the two sections within the integration period, $\langle\tau\rangle$ is biased low. To estimate this bias and get a more robust estimate of the mean transit time, we fit PTTD tails with exponential functions and extrapolate. This estimate, $\langle\tau\rangle_{\infty}$, is also listed in Table 2.

First, note that Fig. 8 a shows that modal transit times computed for all the particles and only the dense ones are very similar (see animations available in the supplemental material at the Journals Online website at http://dx.doi.org/10.1175/JPO-D-13-023s1.txt, http://dx.doi. org/10.1175/JPO-D-13-023s4.m4v, and http://dx.doi.org/ 10.1175/JPO-D-13-023s5.m4v). The implication is that the velocity field carrying the transformed particles is similar to the one carrying the dense particles. Consistently, the horizontal velocity field at the East Greenland shelf break varies little in the vertical [see Magaldi et al. (2011), their Fig. 14, and Brearley et al. (2012), their Fig. $6 \mathrm{~b}]$. For that reason we focus on the travel time statistics computed from all the particles.

\footnotetext{
${ }^{7}$ We use "transit-time distribution" in a different way than Haine and Hall (2002) who refer to the Green's function of the advection-diffusion equation. In their definition, transit time means the elapsed time since a fluid parcel at an interior point last had surface contact. Their transit-time distribution is equivalent to the asymptotic distribution of particle transit times for particles released at the SJ and Angmagssalik sections and integrated backward until they reach the sea surface. This is a different diagnostic than that presented here although both may legitimately be called transit-time distributions.
}

The modal transit times for the SILL particles are very distinct and centered at 5 and 13 days for the Spill Jet and Angmagssalik sections, respectively (Fig. 8a and Table 2). The SILL particles, which are the majority of the particles arriving at the two sections during the simulation, determine the modal peaks for the whole dataset. The SHELF particles also exhibit a clear mode in transit times, but it occurs 5-6 days after that of the SILL. This difference approximates the time for recirculation of the SHELF particles on the Dohrn Bank before they spill off the shelf break. The PTTD of the KANGER set is much broader, with two peaks corresponding to the two events of spilling over the shelf break (at 25 and 50 days at the SJ section and 30-40 days and $>50$ days at the Angmagssalik section). See the animations available in the supplemental material at the Journals Online website at http://dx.doi.org/10.1175/JPOD-13-023s1.txt, http://dx.doi.org/10.1175/JPO-D-13-023s2. m4v, http://dx.doi.org/10.1175/JPO-D-13-023s3.m4v, http:// dx.doi.org/10.1175/JPO-D-13-023s4.m4v, and http://dx. doi.org/10.1175/JPO-D-13-023s5.m4v for visualization of the spilling events.

Remarkably, the shapes of the SILL and SHELF PTTDs at the two sections are very similar (Figs. 8a,b). The PTTD at the Angmagssalik section is delayed by $6-$ 7 days relative to that at the SJ section. This delay provides an estimate for the mean advective time scale between the sections and corresponds to a mean speed of $\sim 0.6 \mathrm{~m} \mathrm{~s}^{-1}$. The similarity of the PTTDs is consistent with advection by the shelf break current downstream of the SJ section (see Fig. 1a), with little dispersion of the particles compared to that occurring in Denmark Strait and on the shelf (Fig. 5a). 
a)

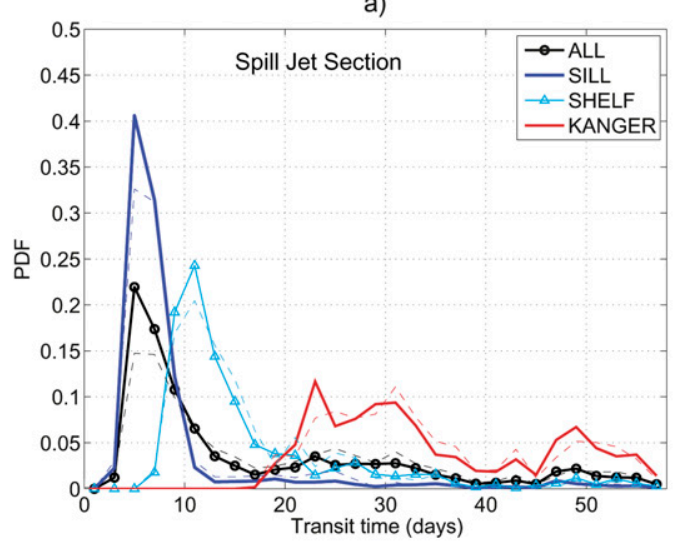

c)

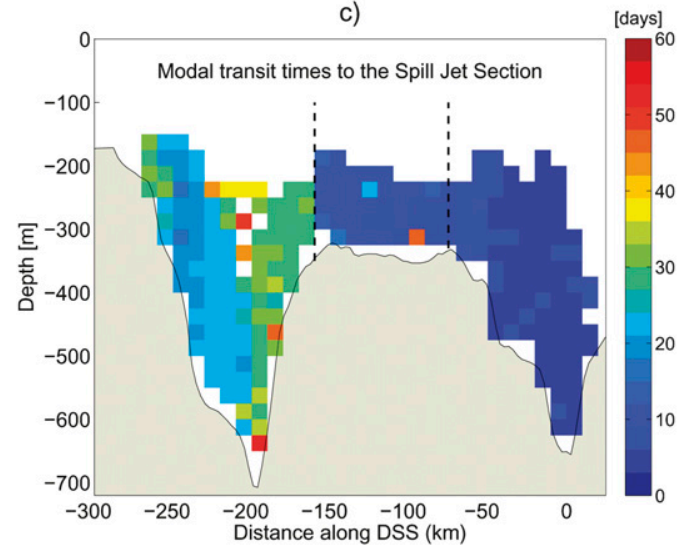

b)

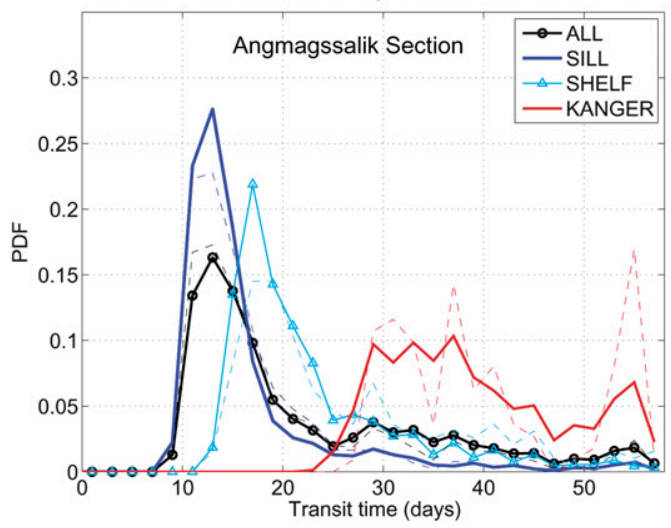

d)

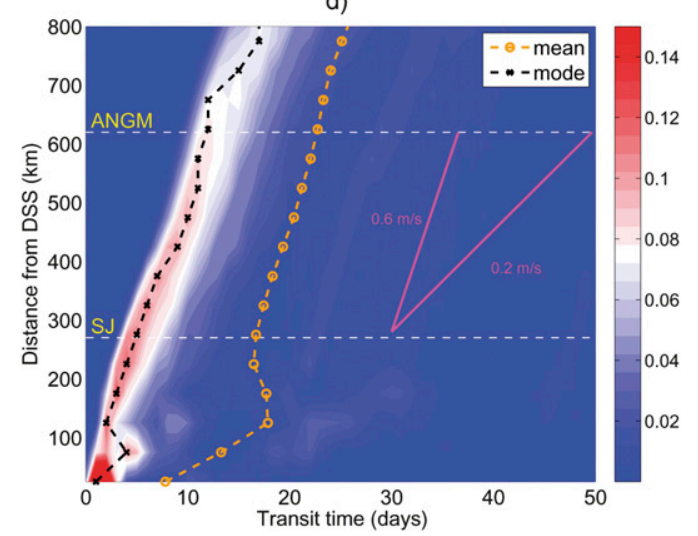

FIG. 8. Transit times from DS. (a) PTTDs for the SJ section color coded by the deployment site. The thick lines show distributions obtained from all particles, the dashed lines show distributions derived from dense particles $\left(\sigma_{\theta} \geq\right.$ 27.8). (b) As in (a), but for the Angmagssalik section. (c) $\mathcal{M}$ to the SJ section projected onto the particle starting location along the DSE section. The black-dashed lines separate particle deployment groups. (d) PTTDs against distance from the DS for all particles. The color shows the fraction of total particle number. The black and orange curves with circles trace the modal peaks and the means of the PTTDs, respectively. The two magenta lines show slopes corresponding to propagation speeds of 0.6 and $0.2 \mathrm{~m} \mathrm{~s}^{-1}$.

The modal transit times for the dense particles arriving at the SJ section, projected onto their deployment location along the DSE section, are shown in Fig. 8c. In general, the transit times decrease with the distance from the Greenland coast. The SILL particles are the fastest ( $\sim 1$ week). The particles deployed on the western side of the Kangerdlugssuaq Trough have smaller $\mathcal{M}$ than the particles deployed on the eastern side by $\sim 1$ week. The explanation is the cyclonic recirculation in the trough that brings the western KANGER particles directly to the shelf break where they spill. The eastern KANGER particles move northwest along the trough first before turning toward the shelf break. The particles released in the quiet interior of the trough take more time to enter the rim circulation and have the greatest $\mathcal{M}$. The figure corresponding to Fig. $8 \mathrm{c}$ for the Angmagssalik section has a similar pattern, but the $\mathcal{M}$ values are $\sim 1$ week longer.
Figure 8d shows the PTTDs against distance from the DSE section. The modal speed calculated from the slope of the line traced by modal peaks (black dashed line) is as low as $0.2 \mathrm{~m} \mathrm{~s}^{-1}$ in the first $50 \mathrm{~km}$ from the Denmark Strait, then increases to over $0.7 \mathrm{~m} \mathrm{~s}^{-1}$ where the particles descend into deep water, and then remains almost constant until the Angmagssalik section $\left(0.58 \mathrm{~m} \mathrm{~s}^{-1}\right.$ as calculated from the slope between 175 and $625 \mathrm{~km}$ ). These speeds are consistent with those estimated from observations by Krauss (1996). He found maximum speeds of $0.5-0.6 \mathrm{~m} \mathrm{~s}^{-1}$ at the overflow interface, associated with the passage of boluses. The mean speeds, derived from the mean transit times (orange line), are lower than the modal speeds, but follow a similar pattern. The mean particle speed is low $\left(\sim 0.2 \mathrm{~m} \mathrm{~s}^{-1}\right)$ within the first $150 \mathrm{~km}$ (where most recirculation takes place; see Fig. 1a and the animations available in the supplemental material at the Journals Online website at 
http://dx.doi.org/10.1175/JPO-D-13-023s1.txt, http://dx. doi.org/10.1175/JPO-D-13-023s2.m4v, http://dx.doi.org/ 10.1175/JPO-D-13-023s3.m4v, http://dx.doi.org/10.1175/ JPO-D-13-023s4.m4v, and http://dx.doi.org/10.1175/JPO$\mathrm{D}-13-023 \mathrm{~s} 5 . \mathrm{m} 4 \mathrm{v}$ ), and increases past the SJ section to $\sim 0.4 \mathrm{~m} \mathrm{~s}^{-1}$ in the shelfbreak jet.

These particle transit-time statistics are derived from an 8 -week-long integration, and $70 \%$ of the particles remain in the domain during this period. Nevertheless, the modal transit times for the SILL and SHELF particles are robust because the simulation period is approximately three times longer than the modal times at Angmagssalik for these particles. Their mean transit time statistics are biased low, but only by 1-2 days (Table 2). It is likely that further modal peaks exist for the KANGER particles at $\tau>57$ days. Thus, it is not possible to obtain robust estimates of $\langle\tau\rangle$ for them from extrapolation although $\langle\tau\rangle$ is likely much longer for KANGER particles than the other sets.

\section{Summary and discussion}

In this study, we explore the fate of dense water at the Denmark Strait. Using a high-resolution model, we deploy over 10000 particles in the model's dense waters at the Denmark Strait and follow them through the Irminger Basin. To our knowledge, this is the first Lagrangian study of the DSO. The main findings and their implications are as follows.

We confirm that the model's deep circulation is realistic. The model accurately reproduces volume transports, hydrographic properties, and overflow structure in the Denmark Strait. Several phenomena previously seen in observations are captured by the model, such as the presence of fresh lenses capping the dense water plume, the westward migration of the front during lowoverflow periods at the sill, and the presence of dense water on the continental shelf (Rudels et al. 1999, 2002). The model volume transports and hydrography compare well with the measurements at the SJ section $(285 \mathrm{~km}$ downstream) and at the Angmagssalik section $(530 \mathrm{~km}$ downstream).

The particles are deployed in waters satisfying $\sigma_{\theta} \geq$ 27.8 on a section crossing the entire Denmark Strait. The section includes the DS sill (where the existing DSO measurements are concentrated), the adjacent shelf, and the Kangerdlugssuaq Trough. The total deployment consists of 10 releases over 5 days. The multiple deployments capture the variability of the overflow through the sill, which occurs in boluses passing every 2-5 days separated by periods of weak dense flow (e.g., Dickson et al. 2008). This work does not address seasonal or interannual changes.

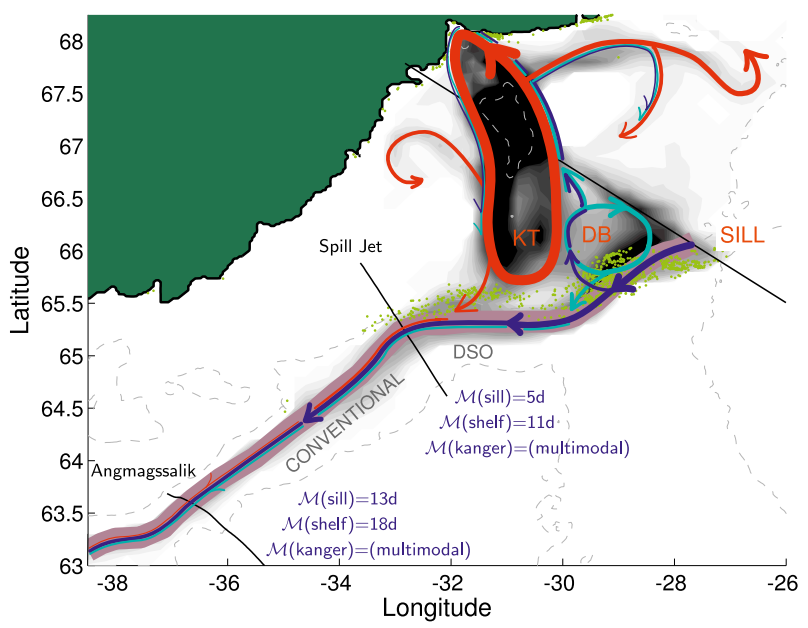

FIG. 9. Fates of dense DS water. The schematic diagram is based on Figs. 3, 4, 5, and 7. It shows the pathways of dense $\left(\sigma_{\theta} \geq 27.8\right)$ Lagrangian particles over 60 days released at the DS. At the DS, dense water is found in the sill (blue), on the adjacent shelf (cyan), and in the KT (red). Over 60 days, these different water masses spread according to the arrows (the width of the arrows is proportional to the square root of the number of particles). There is cyclonic recirculation in the KT and anticyclonic recirculation on the DB. Some of this recirculating water spills over the continental shelf break as shown. Modal transit times $\mathcal{M}$ are indicated for the SJ and Angmagssalik sections (Table 2). The green dots show locations of strongest density loss. The gray shading indicates the distribution of dense particles regardless of starting location (i.e., the superposition of the three distributions in Fig. 4a).

From the particles, we derive pathways, quantify the rates of density transformation, and estimate travel time distributions for transit through the Irminger Basin. The particles show that the DSO plume has other sources in addition to the dense boluses crossing the sill. The particles released on the continental shelf northwest of the sill (SHELF particles) and in the Kangerdlugssuaq Trough (KANGER particles) comprise over $70 \%$ of the particles deployed along the DSE section. These particles cross the shelf and spill over the shelf break, consistent with the observations of dense waters on the shelf (Rudels et al. 1999, 2002; Pickart et al. 2005; Macrander et al. 2007; Brearley et al. 2012). The particles reveal the complexity of the pathways of dense water from Denmark Strait (Figs. 5a and 9). Over threequarters of the particles released in the Denmark Strait sill (the conventional part of the overflow) cascade over the sill and follow the route along the shelf break to the Angmagssalik section. However, almost one-quarter of the SILL particles recirculate anticyclonically on the Dohrn Bank and advect into the Kangerdlugssuaq Trough. Nearly one-half of the dense SHELF particles follow the same route. The other SHELF particles recirculate for about one week on the DB before spilling 
off the shelf break from $-29^{\circ}$ to $-30^{\circ}$ longitude and joining the along-slope route. The KANGER particles recirculate cyclonically in the trough and begin spilling off of the shelf break near the SJ section after 3 weeks. The complex pathways in the strait and on the shelf retard the southward progression of the particles, and after two months nearly $60 \%$ are still within $200 \mathrm{~km}$ of their deployment site. Most of these are from the KANGER and SHELF deployments (78\% and $12 \%$, respectively) and the remaining $10 \%$ are SILL particles swept via the anticyclone on the Dohrn Bank toward the Kangerdlugssuaq Trough.

The SHELF and KANGER particles constitute 17\% and $9 \%$, respectively, of the dense water particles recorded at the Angmagssalik section during the 2-month simulation. This contribution of continental shelf particles is likely an underestimate because most of SHELF and KANGER particles are still in the Denmark Strait when the simulation ends. These Lagrangian results cannot be converted into Eulerian volume transports split into source components at downstream sections because the particles crossing a particular section sample only a subset of all the possible upstream origins.

Property time series along the particle trajectories visualize water mass transformation processes. We verify that particles recorded along the conventional DSO route evolve consistently with the hydrographic observations by Girton and Sanford (2003) of the mean DSO plume position and density. The particles reproduce the rapid density decrease in the first $200 \mathrm{~km}$ from the sill, followed by little density change between the SJ and the Angmagssalik sections, consistent with observations (Voet and Quadfasel 2010). This gives confidence that our short-time particle experiment represents the observed properties of the dense waters.

There are two main regions of rapid transformation along the slope. The first is immediately downstream of the sill where dense boluses descend into the Irminger Basin. The second is upstream of the SJ section, where KANGER particles spill off the shelf. In both places the dense waters mix with the warm salty Atlantic waters, in line with observations by Tanhua et al. (2005) and Brearley et al. (2012). Notably, the densest particles in the along-slope flow at the SJ section are those released on the shelf. This is consistent with Rudels et al. (2003) and Falina et al. (2012), who observed shelf water with $\sigma_{\theta} \sim 27.9$ and postulated that it feeds the DSO after spilling over the shelf break. These SHELF particles avoid the regions of intense mixing and undergo relatively little transformation. We also find strong transformation farther north, on the shelf close to the Greenland coast, where dense waters from the Kangerdlugssuaq Trough mix with Polar Surface Water, again in line with Tanhua et al. (2005). Thus, Atlantic and Polar waters contribute to the overflow. Variability in these water masses may imprint on the dense overflow to the North Atlantic.

As a result of this transformation, the Denmark Strait waters decrease their density. At the Angmagssalik section, $30 \%$ of the particles have transformed to intermediate density $\left(27.7 \leq \sigma_{\theta}<27.8\right)$ within the 2 month simulation. Therefore, defining DSOW in the Irminger Basin with a density (or temperature) criterion is misleading because dense water at Denmark Strait is transformed by mixing. On this issue, Brearley et al. (2012) analyzed velocity and oxygen data from the SJ section and observed well-ventilated, southwardflowing water as light as $\sigma_{\theta}=27.7$ with DSO oxygen levels. Our results show that a large part of this water may have been at Denmark Strait with $\sigma_{\theta} \geq 27.8$. A DSOW definition that accounts for water mass transformation is needed to accurately track the fate of dense water at Denmark Strait. The Lagrangian diagnostics presented here meet this need.

Finally, we estimate transit times from Denmark Strait. The modal transit time for the particles released at the DS sill to the SJ section is 5-6 days. The corresponding speed is $0.65 \mathrm{~m} \mathrm{~s}^{-1}$. The modal transit time from the sill to the Angmagssalik section is 2-3 weeks. The particles released on the shelf adjacent to the sill recirculate before spilling over the shelf break and joining the overflow from the sill, and their modal transit times are longer by about a week. The mean transit times are 1-6 days longer than the modal times for these two sets of particles. The KANGER particles recirculate in the Denmark Strait for several weeks $(80 \%$ remain within $200 \mathrm{~km}$ of their release site during the 2-month simulation). The KANGER particle transit time distributions to the SJ and Angmagssalik sections are broad and the mean transit times have not converged. Their modal transit times are 3 and 5 weeks to the SJ and Angmagssalik sections respectively, significantly longer than for the particles released near and at the DS sill.

This study addresses the fate of the dense waters at the DS. It relies on particle deployments at the DS and the forward integration of their trajectories. It focuses on pathways and travel times to the sections downstream and on transformation of the dense waters. It is also possible to diagnose the origin of dense waters at sections in the Irminger Basin. Addressing this question requires particle deployments at the sections of interest and the backward integration of their trajectories. Such an experiment would reveal the origins of water entrained into the DSO. We will address this issue in a future study. Future work will also quantify the mixing rates and eddy fluxes responsible for the density transformation and 
entrainment in the overflow, which is essential to the proper parameterization of these processes.

Our modeling study has elucidated the complexity of the dense overflow in the Irminger Basin that is not apparent in the available observations (see Fig. 9 for a schematic summary). In particular, we have mapped the dense water pathways on the shelf and showed that this water makes an important contribution to the overflow. If these findings are confirmed by future measurements, our perception of Denmark Strait Overflow should be recast to include dense water masses on the continental shelf with different pathways, histories, and time scales. Such an effort to observe these components of the Denmark Strait circulation is an important priority.

Acknowledgments. The authors acknowledge comments and inspiring discussions with Robert Pickart, Wilken-Jon von Appen, Kial Stewart, Stephen Jeffress, and Alex Fuller. Special thanks to Kial Stewart for help with digital media production. This work was supported in part by NSF Grants OCI-108849, OCE-0726640, and OCI-0904338. Data-intensive computations have been performed on the Johns Hopkins Data-Scope funded by OCI-1040114.

\section{REFERENCES}

Adcroft, A., and J.-M. Campin, 2004: Rescaled height coordinates for accurate representation of free-surface flows in ocean circulation models. Ocean Modell., 7 (3-4), 269-284, doi:10.1016/ j.ocemod.2003.09.003.

Brearley, J. A., R. S. Pickart, H. Valdimarsson, S. Jonsson, R. W. Schmitt, and T. W. N. Haine, 2012: The East Greenland boundary current system south of Denmark Strait. Deep-Sea Res. I, 63, 1-19.

Bruce, J. G., 1995: Eddies southwest of the Denmark Strait. DeepSea Res. I, 42, 13-29.

Chassignet, E. P., and Coauthors, 2009: US GODAE global ocean prediction with the Hybrid Coordinate Ocean Model (HYCOM). Oceanography, 22, 64-75.

Dickson, B., and Coauthors, 2008: The overflow flux west of Iceland: Variability, origins and forcing. Arctic-Subarctic Ocean Fluxes. Defining the Role of the Northern Seas in Climate, R. R. Dickson, J. Meincke, and P. Rhines, Eds., Springer Science and Business Media, 443-474.

Dickson, R. R., and J. Brown, 1994: The production of North Atlantic Deep Water: Sources, rates and pathways. J. Geophys. Res., 99 (C6), 12319-12341.

Döös, K., 1995: Interocean exchange of water masses. J. Geophys. Res., 100 (C7), 13 499-13514.

Dutkiewicz, S., L. Rothstein, and T. Rossby, 2001: Pathways of cross-frontal exchange in the North Atlantic Current. J. Geophys. Res., 106 (C11), 26917-26928.

Falina, A., A. Sarafanov, H. Mercier, P. Lherminier, A. Sokov, and N. Daniault, 2012: On the cascading of dense shelf waters in the Irminger Sea. J. Phys. Oceanogr., 42, 2254-2267.

Girton, J. B., and T. B. Sanford, 2003: Descent and modification of the overflow plume in the Denmark Strait. J. Phys. Oceanogr., 33, 1351-1364.
- , — a and R. H. Käse, 2001: Synoptic sections of the Denmark Strait Overflow. Geophys. Res. Lett., 28, 1619-1622.

Haine, T. W. N., and T. M. Hall, 2002: A generalized transport theory: Water mass composition and age. J. Phys. Oceanogr., 32, 1932-1946.

—, S. Zhang, G. W. K. Moore, and I. A. Renfrew, 2009: Impact of high-resolution, high-frequency meteorological forcing on Denmark Strait ocean circulation. Quart. J. Roy. Meteor. Soc., 135, 2067-2085, doi:10.1002/qj.505.

Hall, S., S. R. Dye, K. J. Heywood, and M. R. Wadley, 2011: Wind forcing of the salinity anomalies in the Denmark Strait Overflow. Ocean Sci., 7, 821-834, doi:10.5194/os-7-821-2011.

Jackett, D. R., and T. J. McDougall, 1995: Minimal adjustment of hydrostatic profiles to achieve static stability. J. Atmos. Oceanic Technol., 12, 381-389.

Jochumsen, K., D. Quadfasel, H. Valdimarsson, and S. Jónsson, 2012: Variability of the Denmark Strait overflow: Moored time series from 1996-2011. J. Geophys. Res., 117, C12003, doi:10.1029/2012JC008244.

Kalnay, E., and Coauthors, 1996: The NCEP/NCAR 40-Year Reanalysis Project. Bull. Amer. Meteor. Soc., 77, 437471.

Käse, R. H., and A. Oschlies, 2000: Flow through Denmark Strait. J. Geophys. Res., 105 (C12), 28527-28546.

_ J. B. Girton, and T. B. Sanford, 2003: Structure and variability of the Denmark Strait Overflow: Model and observations. J. Geophys. Res., 108, 3181, doi:10.1029/2002JC001548.

Köhl, A., 2010: Variable source regions of Denmark Strait and Faroe Bank Channel overflow waters. Tellus, 62A, 551-568.

Krauss, W., 1996: A note on overflow eddies. Deep-Sea Res. I, 43, 1661-1667, doi:10.1016/S0967-0637(96)00073-8.

Large, W. G., J. C. McWilliams, and S. C. Doney, 1994: Oceanic vertical mixing: A review and a model with a nonlocal boundary layer parameterization. Rev. Geophys., 32, 363-403.

Macrander, A., R. H. Käse, U. Send, H. Valdimarsson, and S. Jónsson, 2007: Spatial and temporal structure of the Denmark Strait Overflow revealed by acoustic observations. Ocean Dyn., 57, 75-89.

Magaldi, M. G., T. W. N. Haine, and R. S. Pickart, 2011: On the nature and variability of the East Greenland Spill Jet: A case study in summer 2003. J. Phys. Oceanogr., 41, 2307-2327.

Pickart, R. S., D. J. Torres, and P. S. Frantantoni, 2005: The East Greenland Spill Jet. J. Phys. Oceanogr., 35, 1037-1053.

Rossby, T. H., D. Dorson, and J. Fontaine, 1986: The RAFOS system. J. Atmos. Oceanic Technol., 3, 672-679.

- M. D. Prater, and H. Søiland, 2009: Pathways of inflow and dispersion of warm waters in the Nordic seas. J. Geophys. Res., 114, C04011, doi:10.1029/2008JC005073.

Rudels, B., P. Eriksson, H. Grönvall, R. Hietala, and J. Launiainen, 1999: Hydrographic observations in the Denmark Strait in fall 1997, and their implications for the entrainment into overflow plume. Geophys. Res. Lett., 26, 1325-1328.

_ E. Fahrbach, J. Meincke, G. Budeus, and P. Eriksson, 2002: The East Greenland Current and its contribution to the Denmark Strait Overflow. ICES J. Mar. Sci., 59, 1133-1154, doi:10.1006/jmsc.2002.1284.

, P. Eriksson, E. Buch, G. Budeus, and E. Fahrbach, 2003: Temporal switching between sources of the Denmark Strait overflow water. Proc. ICES Marine Science Symp.: Hydrobiological variability in the ICES area 1990-1999, Vol. 219, Edinburgh, United Kingdom, International Council for the Exploration of the Sea, 319-325.

Serra, N., R. Käse, A. Köhl, D. Stammer, and D. Quadfasel, 2010: On the low-frequency phase relation between the Denmark 
Strait and the Faroe Bank Channel overflows. Tellus, 62, 530550, doi:10.1111/j.1600-0870.2010.00445.x.

Søiland, H., M. D. Prater, and T. Rossby, 2008: Rigid topographic control of currents in the Nordic seas. Geophys. Res. Lett., 35, L18607, doi:10.1029/2008GL034846.

Song, T., and T. Rossby, 1997: Analysis of Lagrangian potential vorticity balance and lateral displacement of water parcels in Gulf Stream meanders. J. Phys. Oceanogr., 27, 325-339.

Spall, M. A., and J. F. Price, 1998: Mesoscale variability in the Denmark Strait: The PV outflow hypothesis. J. Phys. Oceanogr., 28, 1598-1623.

Tanhua, T., K. A. Olsson, and E. Jeansson, 2005: Formation of Denmark Strait Overflow Water and its hydro-chemical composition. J. Mar. Syst., 57, 264-288.

,-- , and -2008 : Tracer evidence of the origin and variability of Denmark Strait Overflow Water. Arctic-Subarctic Ocean Fluxes. Defining the Role of the Northern Seas in
Climate, R. R. Dickson, J. Meincke, and P. Rhines, Eds., Springer Science and Business Media, 475-503.

Voet, G., and D. Quadfasel, 2010: Entrainment in the Denmark Strait Overflow plume by meso-scale eddies. Ocean Sci., 6, 301-310, doi:10.5194/os-6-301-2010.

Whitehead, J. A., A. Leetmaa, and R. A. Knox, 1974: Rotating hydraulics of strait and sill flows. Geophys. Fluid Dyn., 6, 101125.

Yashayaev, I., and B. Dickson, 2008: Transformation and fate of overflows in the northern North Atlantic. Arctic-Subarctic Ocean Fluxes. Defining the Role of the Northern Seas in Climate, R. R. Dickson, J. Meincke, and P. Rhines, Eds., Springer Science and Business Media, 505-526.

Zhang, H.-M., J. J. Bates, and R. W. Reynolds, 2006: Assessment of composite global sampling: Sea surface wind speed. Geophys. Res. Lett., 33, L17714, doi:10.1029/ 2006 GL027086. 